\title{
MOT ETT BREDARE ARKETEXTUALITETSBEGREPP: DEN AUGUSTINSK-LUTHERSKA DISKURSTYPEN I BIRGITTA TROTZIGS DYKUNGENS DOTTER
}

\author{
KRZYSZTOF BAK
}

\begin{abstract}
Towards a Broader Notion of Architextuality. The AugustinianLutheran Type of Discourse in Birgitta Trotzig's Dykungens dotter (The Marsh King's Daughter)

This article has three aims, all of them related to the theory and practice of intertextuality. Firstly, the article makes an attempt to reconstruct the Augustinian-Lutheran type of discourse. A number of modern theologians and historians of philosophy have observed that the main currents within Christian theology have their basis in a specific discourse organization of textual utterances. With reference to these observations, the article maps out some dominant features of Augustine's and Luther's discoursive practices. The type of discourse thus reconstructed contains grammatical, logical-argumentative, narrative and rhetoric-figurative characteristics, and - as a matter of fact - it manifests a high degree of applicability in the field of literary studies. Secondly, the article applies the reconstructed type of discourse to analyze a masterpiece of Swedish twentieth-century literature, the novel Dykungens dotter (The Marsh King's Daughter, 1985) by Birgitta Trotzig (1929-2013). In several interviews, Trotzig makes evidently contradictory remarks on Augustine and Luther. She dissociates herself from their anthropology at the same time as she hints that their view of human conditions has made a deep impression on her. The article's application intends to throw light on this precarious hermeneutic situation. The intense presence of the Augustinian-Lutheran type of discourse in the novel made apparent through the application indicates that an interpretation of Trotzig's writings by means of Augustinian-Lutheran intertexts is hermeneutically motivated in spite of her own negative declarations. Thirdly, the article makes use of the reconstructed type of discourse in order to examin Gérard Genette's notion of architextuality. There is a theoretical incongruence in his notion. On an explicit definitory level, architextuality includes all types of discourse and modes of enunciation. On a conteptual level, however, the notion of architextuality is constructed on the pattern of literary genres. The article's application demonstrates that Genette's notion requires some corrections to live up to its definitory commitments. The Augustinian-Lutheran architext comes into conflict with some of Genette's linguisticly construed structuralistic categories and demands a more discoursive and hermeneutic way of thinking.
\end{abstract}


Keywords: Architextuality, Birgitta Trotzig, Dykungens dotter, Gérard Genette, structuralism, Augustinian-Lutheran type of discourse, hermeneutics, Christian anthropology

Denna artikel har tre syften, alla tre kopplade till intertextualitetsproblematiken. För det första vill den på det teoretiska planet bidra till en precisering av arketextualitetsbegreppet. För det andra har den till syfte att rekonstruera - eller snarare konstruera en specifik arketext som kan förväntas ha en stor hermeneutisk potential. För det tredje avser den att med hjälp av denna arketext analysera en modern svensk roman som snabbt fått klassikerstatus: Birgitta Trotzigs Dykungens dotter (1985). Romanen är en brett anlagd samhällsfresk som genom att följa en rotlös skånsk arbetarfamilj i tre generationer skildrar ett av det svenska 1900-talets största sociala omvälvningar: flyttningen från landet till staden. I romanens öppningsscen vandrar en ung, gravid kvinna, senare kallad Mojan, från Kåseberga på yttersta Österlen till Kristianstad. Hon får så småningom jobb på en yllefabrik och lever som en slav under sin spolmaskin i tjugoåtta år tills hon flyttar till den ännu större fabriksstaden Malmö. Hennes dotter, omtalad som flickan, klarar inte fabriksvärldens hårda villkor, försörjer sig i stället som prostituerad i Malmö och dör en förtidig död. Flickans son, pojken, rycks genom barnavårdsnämndens beslut bort från sin biologiska mor, placeras på fosterhem, blir kriminell och skjuts ihjäl vid ett försök att fly från den rättspsykiatriska klinik han internerats på. Romanens övriga två centralgestalter, dykungen och gårdskarlen, den förra Mojans älskare och flickans pappa, den senare hennes äkta man, kommer även de från landet och misslyckas med att finna sig till rätta i den urbana världen.

Att just Dykungens dotter valts som föremål för min analys beror inte minst på att romanen är baserad på en intensiv intertextuell och arketextuell dialog. Då boken kom ut i april 1985 hade intertextualitet sedan länge varit ett etablerat begrepp såväl i Trotzigs egna litterära artiklar som i den svenska kulturdebatten i stort, och i de flesta recensioner fungerade romanens samtal med andra texter som en dominerande receptionsstrategi. ${ }^{1}$

De tre målsättningar jag inledningsvis formulerat kan tyckas vara en alltför omfattande uppgift för en kortare vetenskaplig artikel, men de kommer inte att realiseras var för sig utan inom ramen för en och samma arketextuella applikation. Eftersom de arketextuella rön min rekonstruktion bygger vidare på har en preliminär karaktär bör resonemanget betraktas som ett experiment. Min förhoppning är förstås att denna pilotstudie kommer att visa att intertextualitetsforskningen, som under de senaste åren överskuggats av andra litteraturvetenskapliga trender, fortfarande har stora utvecklingsmöjligheter.

\section{Frågeställningar}

Av de många analytiska begreppskomplex som intertextualitetsteoretiker utarbetat har Gérard Genettes taxonomi, framlagd först skissartat i Introduction à l'architexte

1 Receptionen av Dykungens dotter och dess intertextuella strategier diskuteras utförligt i min monografi Den intersubjektiva synden i Birgitta Trotzigs Dykungens dotter, Kraków 2005, s. $11 \mathrm{ff}$. Intertexualitetsbegreppet använder Trotzig bland annat i sitt svar på "Enkät om Ekelöf: vad han betytt för lyriker och andra”, Allt om Böcker 1984/2, s. 12; jfr Bak, Den intersubjektiva synden, s. 108f. 
(1979) och därefter mer detaljerat i Palimpsestes. La littérature au second degré (1982), fått störst genomslag. Den har visserligen underkastats en del kritik, ${ }^{2}$ men till skillnad från bemötandet av Genettes narratologiska begreppsapparat har de teoretiska diskussionerna inte lett fram till några nämnvärda korrigeringar av hans intertextualitetsteoretiska distinktioner. Hans kategorier fungerar numera som intertextuell standardtypologi i litteraturvetenskapliga uppslagsverk. ${ }^{3}$ Samma höga status åtnjuter Genettes kategorier i de senast utgivna skandinaviska introduktionsböckerna i litteraturvetenskap. ${ }^{4}$ I denna artikel vill jag granska några komponenter i Genettes teori, dock inte genom att anamma den tidigare kritikens övervägande teoretiska orientering utan genom att bemöta hans systematik på den punkt som allmänt anses vara dess största värde: dess pragmatism. ${ }^{5}$ Min idé är att genomföra en sorts marginal graft och konfrontera Genettes typologi med ett intertextuellt fenomen som rent formellt omfattas av hans taxonomi men som ligger utanför de kognitiva mönster som utgör fundamentet i hans system. ${ }^{6}$ Den fråga jag vill ställa är om och hur detta breddade intertextuella perspektiv kan påverka reliabiliteten i hans bärande bestämningar.

Ett påfallande drag i Genettes typologi är att den - i motsats till exempelvis Linnés klassificeringssystem - konstituerar sina grundtyper utifrån växlande kriterier. Intertextualitet i Genettes snäva betydelse definieras via de intertextuella signalernas struktur, paratextualitet via signalernas placering i texten, metatextualitet via textens relation till sin intertext osv. ${ }^{7}$ Taxonomier som bygger på den sortens oenhetliga bestämningar ett givet exempel är det litterära genresystemet - brukar ha en mycket öppen karaktär och kan lätt utvidgas åt olika håll. Genettes klassifikation låter sig inte överskridas på samma sätt. Den viktigaste orsaken är att han låter sin femte och sista intertextuella typ, arketextualiteten, inte bara inkludera de övriga fyra typerna utan i princip alla former av textualitet. I Genettes begreppsbestämning är arketexten "omniprésent, au-dessus, au-dessous, autour du texte". Vilken ny intertextualitetstyp man än uppfinner, ingår den

2 Jfr Thaïs Morgan, "The Space of Intertextuality", i: Intertextuality and Contemporary American Fiction, red. Patrick O’Donnell \& Robert Con Davis, Baltimore-London 1989, s. 266ff.; Karlheinz Stierle, "Werk und Intertextualität", i: Dialog der Texte. Hamburger Kolloquium zur Intertextualität, red. Wolf Schmid \& Wolf-Dieter Stempel, Wien 1983, s. 23f.; Manfred Pfister, "Konzepte der Intertextualität", i: Intertextualität. Formen, Funktionen, anglistische Fallstudien, red. Ulrich Broich \& Manfred Pfister, Tübingen 1985, s. 16f.; Graham Allen, Intertextuality, Abingdon 2011, s. $92 \mathrm{ff}$.

3 Jfr Barbara Godard, "Intertextuality", i: Encyclopedia of Contemporary Literary Theory. Approaches, Scholars, Terms, red. Irena M. Makaryk, Toronto 1993, s. 570; Dominique Maingueneau, "Intertextualite", i: Dictionnaire d'analyse du discours, red. Patrick Charaudeau \& Dominique Maingueneau, Paris 2002, s. 328; Matias Martinez, "Intertextualität", i: Metzler Lexikon Literatur. Begriffe und Definitionen, red. Dieter Burdof m.fl., Stuttgart-Weimar 2007, s. 357f. För att undvika begreppslig och terminologisk förbistring håller jag mig till litteraturvetenskaplig standardvokabulär och betraktar intertextualitet som en samlingskategori som omfattar alla typer av intertextuella relationer. De gånger uttrycket intertextualitet används i Genettes snävare betydelse kommer detta att signaleras.

4 Jfr Elisabeth Friis, "Intertextualitet", i: Litteratur. Introduktion till teori och analys, red. Lasse Horne Kjældgaard m.fl., Lund 2015, 150ff.; Ljubica Miočević, "Intertextualitet", i: Litteraturvetenskap I, red. Sigrid Schottenius Cullhed m.fl., Lund 2020, s. 194.

5 Jfr Christian Moraru, "Intertextuality", i: Routledge Encyclopedia of Narrative Theory, red. David Herman m.fl., London-New York 2008, s. 260; Allen, s. 206; Friis, s. 150.

6 Ur en besläktad pragmatisk aspekt granskas Genettes typologi i Ann Jefferson, "Autobiography as Intertext. Barthes, Sarraute, Robbe-Grillet", i: Intertextuality. Theories and Practices, red. Michael Worton \& Judith Still, Manchester-New York 1990, s. 110ff.

7 Gérard Genette, Palimpsestes. La littérature au second degré, Paris 1982, s. $8 \mathrm{ff}$. 
i sista hand i "ce réseau d'architexture" och lyder arketextualitetens bestämningar. ${ }^{8}$ Ytterligare en komplikation i Genettes taxonomi är att hans arketextualitetsbegrepp, som på det formellt-definitoriska planet förses med den gudomliga hypostasens universalitet, rent kognitivt konstrueras utifrån en mycket snäv tankemodell. I Introduction à l'architexte är alla de arketextuella komponenter som diskuteras på ett eller annat vis relaterade till det litterära genresystemet. ${ }^{9}$ I Palimpsestes görs en likartad koppling mellan textens arketextualitet och dess "qualité générique". ${ }^{10}$ I en parentesanmärkning nämner visserligen Genette att "le genre n'est qu'un aspect de l'architexte", men i sin exemplifiering begränsar han sig till generiska kategorier och låter ingen annan arketextuell formation påverka sitt arketextualitetskoncept. ${ }^{11}$

Denna artikel vill ställa just en sådan icke-generisk arketext i fokus. Enligt Genettes begreppsbestämning omfattar arketexter alla slags "types de discours, modes d'énonciation". ${ }^{12}$ De extremt breda kategorierna diskurs och diskurstyp, som inbegriper grammatik, metaforik, argumentationsformer, epistemologiska presuppositioner, idékontexter etc. och som dessutom vill kombinera dessa element på ett maximalt flexibelt, icke-systematiskt sätt, gör det möjligt att söka arketexter inom vitt skilda discipliner. ${ }^{13}$ Ett sådant område är teologin. Som en rad teologer och filosofihistoriker observerat kan inom kristendomens ramar urskiljas ett antal tankeparadigm som ofta, om än inte alltid, motsvarar konfessionella tillhörigheter. Snarare än av explicit formulerade dogmer konsolideras de av olika diskursiva praktiker, som är kopplade till hur man formulerar teologiska frågor, vilka kognitiva argumentationsmönster man privilegierar, ur vilket perspektiv och med vilka språkliga strategier man belyser de diskuterade problemen. ${ }^{14}$ Forskningen kring dessa teologiska diskurstyper befinner sig fortfarande i ett initialt stadium men har ändå hunnit formulera en rad tänkvärda resultat. Med stöd i dem ska jag rekonstruera en sådan teologisk arketext och konfrontera den med Genettes generiskt styrda arketextualitetsförståelse.

Mitt val av arketext har inte bara en teoretisk utan också en applikativ motivering. Som bland andra Paul Ricœur demonstrerat sker en texts betydelseproduktion inte helt odeterminerat utan inom en given strukturell och diskursiv ram. ${ }^{15}$ Den arketextuella analysen kan därmed bidra till att skapa semantisk tillslutning i tolkningsarbetet, särskilt

8 Gérard Genette, Introduction à l'architexte, Paris 1979, s. 89.

9 Genette, Introduction, s. 7ff. och passim.

10 Genette, Palimpsestes, s. 11.

11 Ibid.

12 Ibid., s. 7; jfr förf:s Introduction, s. 88ff.

13 Jfr Martin Jay, Downcast Eyes. The Denigration of Vision in Twentieth-Century French Thought, Berkeley 1993, s. 16; Dominique Maingueneau, "Discours" \& "Type de discours", i: Dictionnaire d'analyse, s. $185 \mathrm{ff}, 592$.

14 Jfr Yves M.-J. Congar, "Neuf Cents ans après. Notes sur le 'Schisme oriental'”, i: 1054-1954. L'Église et les Églises. Neuf siècles de douloureuse séparation entre l'Orient et l'Occident. Études et travaux sur l'unité chrétienne offers à Dom Lambert Beauduin, Chevetogne 1954, I, s. 3ff., 43ff. och passim; förf:s La Foi et la Théologie, Tournai 1962, 197ff., 233ff.; Hans-Joachim Schulz, ”Die 'Höllenfahrt' als 'Anastasis'. Eine Untersuchung über Eigenart und dogmengeschichtliche Voraussetzungen byzantinischer Osterfrömmigkeit", Zeitschrift für katholische Theologie 81 (1959), s. 1ff.; Nicolas Zernov, "Rome and Orthodoxy. Is Reunion Possible?", i: Pluralisme et Ecuménisme en Recherches Théologiques. Mélanges offerts au R.P. Dockx, O.P., Paris 1976, s. 237ff.

15 Jfr Paul Ricœur, "Qu'est-ce qu'un texte? Expliquer et comprendre", i: Hermeneutik und Dialektik. Aufsätze II, red. Rüdiger Bubner m.fl., Tübingen 1970, s. $196 f f$. 
då traditionella betydelsedeterminerande indicier stödjer flera olika tolkningsalternativ. I ett sådant labilt hermeneutiskt läge befinner sig en uttolkare av Birgitta Trotzigs författarskap inte minst till följd av hennes motsägelsefulla uttalanden om Augustinus och Luther. $\AA$ ena sidan har hon medgett att ingen teologisk formulering berört henne djupare än en sats ur öppningskapitlet i Confessiones som hon ofta citerar: "Du har skapat oss och vårt hjärta är oroligt tills det finner ro i dig". ${ }^{16}$ I den nyare Augustinusforskningen råder påfallande enighet om att påståendet i ett nötskal rymmer kyrkofaderns sena antropologi, som kom att utgöra grunden för Luthers människosyn. ${ }^{17} \AA$ A andra sidan har Trotzig vid olika tillfällen i bestämda ordalag distanserat sig från den augustinsk-lutherska människouppfattningen. ${ }^{18}$ Denna pilotstudie är tänkt som ett försök att med hjälp av en arketextuell analys stabilisera denna prekära hermeneutiska situation. Augustinus och Luthers radikala antropologi har sin förutsättning i specifika diskursiva praktiker, som på många punkter skiljer sig från textorganisationen hos Thomas av Aquino, den katolska nyteologin eller den grekiska patristiken, de teologiska vägvisare Trotzig helst identifierar sig med. ${ }^{19}$ Med utgångspunkt i andras och egen forskning på området ska jag rekonstruera några centrala element i denna augustinsk-lutherska arketext och undersöka i vilken mån de är närvarande i Dykungens dotter.

Vad som gör Dykungens dotter extra lämplig som objekt för min applikation är att kristendomens uppenbarelsekällor intar en dominerande ställning bland romanens intertexter. I förstautgåvans baksidestext, signerad Birgitta Trotzig själv, omnämns H. C. Andersens "Dynd-Kongens Datter" som en viktig inspiration bakom romanens gestaltkonstruktion. De flesta recensenter och merparten av de litteraturforskare som ägnat sig åt Trotzigs roman har följt baksidestextens - och romantitelns - paratextuella signaler: deras intertextuella intresse upptas nästan helt av den andersenska konstsagan. ${ }^{20}$ Men som jag utförligt visat i monografin Den intersubjektiva synden i Birgitta Trotzigs Dykungens dotter (2005) döljer romanens hänvisningar till "Dynd-Kongens Datter" en viktigare och djupare intertextuell referens, den kristna antropologin, som både berättaren och författaren själv ger status som verkets yttersta, otranscenderbara förståelseho-

16 Lars Collmar, "Varför kallas mina böcker svarta? Verkligheten är ju mycket värre”, Vår Kyrka 47 (1973), s. 7; [Birgitta Trotzig \& Martin Lönnebo], "Mystikens språk och erfarenhet. Ett samtal mellan Birgitta Trotzig och Martin Lönnebo", i: Mystik. Samtal och föredrag, Linköping 1993, s. 8; Maciej Zaremba, "'Jag går i vilka kyrkor jag vill'", Dagens Nyheter 20.12.1998. Den citerade satsen ingår i Augustinus, Confessiones 1,1,1 (PL 32,661).

17 Jfr Erich Lampey, Das Zeitproblem nach den Bekenntnissen Augustins, Regensburg 1960, s. 9; Martin Skutella, "Notes complémentaires", i: Augustinus, Les Confessions. Livres I-VII, red. Martin Skutella, Paris 1962, s. 648.

18 Jfr Agneta Pleijel, "Människan, skapelsen, skapandet. Ett samtal med Birgitta Trotzig", Ord och Bild 91/1 (1982), s. 10; Pierre Kullbom, "Religion, litteratur och nutid - ett samtal med Birgitta Trotzig", Signum 12/3 (1986), s. 72; K. Arne Blom, '”Jag tyckte Martin Luther hade fel!'”, Tidningen Boken 12/5 (1998), s. 14.

19 Jfr Otto Hermann Pesch, Theologie der Rechtfertigung bei Martin Luther und Thomas von Aquin. Versuch eines systematisch-theologischen Dialogs, Mainz 1967, s. 929ff.; Kurt Flasch, "Logik des Schreckens", i: Logik des Schreckens. Augustinus von Hippo. De diversis quaestionibus ad Simplicianum I 2, red. Kurt Flasch, Mainz 1995, s. 46f.; Aimé Solignac, "Les excès de l"intellecus fidei' dans la doctrine d'Augustin sur la grâce", Nouvelle Revue Théologique 110/6 (1988), s. 848. Sina teologiska preferenser kommenterar Trotzig i Pleijel, s. 10; Trotzig \& Lönnebo, s. 8f.; Birgitta Trotzig, "Efterskrift 1974", i: Teilhard de Chardin, red. Jarl Hemberg, Stockholm 1975, s. 64ff.; Lars Collmar, "Själv håller jag mig till den negativa teologin", Vår Kyrka 116/27-28 (1977), s. 2 f.

20 Jfr Bak, Den intersubjektiva synden, s. $12 \mathrm{f}$. 
risont: i en intervju publicerad i samband med utgivningen av Dykungens dotter kallar Trotzig sin roman "en väldigt religiös bok". ${ }^{21}$ Den kristna antropologins intertextuella företräde märks inte minst i romanens arketextuella struktur som starkt präglas av bibliska och kristna genrer, bland annat helgonlegenden, hymnen, klagosången, kärleksvisan, det profetiska ordet, parabeln, apokalypsen, barndomshistorien, passionshistorien och predikan. Huvudfrågan i denna artikel är huruvida romanens arketextuella dialog med den kristna traditionen vid sidan av denna generiskt baserade arketextualitet även inkluderar den icke-generiska augustinsk-lutherska diskurstypen. ${ }^{22} \mathrm{Om}$ romanen visar sig rymma denna arketext, är en augustinsk-luthersk tolkning av Trotzigs textkorpus legitimerad, vad än de författarintentionella utsagorna deklarerar.

\section{Applikation}

Medan många av kristendomens centrala tankeparadigm har en syntetisk orientering, privilegierar Augustinus och Luther analytiska tankestrategier. Deras vanligaste metod är att särskilja, avgränsa, införa distinktioner: mellan njutande och nyttjande, mellan evangelium och lag, mellan amor Dei och amor sui. ${ }^{23}$ Med stor emfas skildras själva åtskiljandeprocessen. Augustinus lägger ner ansenlig teologisk energi på att beskriva hur civitas terrena avskiljs från civitas Dei. ${ }^{24}$ De separerade begreppens stabilitet säkras genom huvudsakligen tre epistemologiska manövrer, som genom sin rigorism kan sägas falla under Eduard von Hartmanns och Carl Schmitts diagnos av "die Tyrannei der Werte". 25 För det första underkastas var och en av de urskilda kategorierna en långtgående intern homogenisering. Medan Thomas av Aquino gärna arbetar med graderande skalor, ten-

21 Nils Gunnar Nilsson, "'Den årstid där evigheten börjar'”, Sydsvenska Dagbladet 7.4.1985. I samma intervju tilldelar Trotzig "Dynd-Kongens Datter" en underordnad plats bland romanens intertexter. Den andersenska konstsagans och den kristna antropologins intertextuella intensitet i Dykungens dotter jämför jag i Den intersubjektiva synden, s. 13ff. Den kristna antropologins roll som romanens centrala intertextuella referens framhåller jag också i en rad artiklar, bl.a. "Varats avigsida. Om en ontisk tolkning av Birgitta Trotzigs Dykungens dotter", Kritiker 93/17-18 (2010), s. 117ff. och "Subjektivitetens tätaste mörker. Om tolkning av bildkonst hos Birgitta Trotzig”, i: Det åskådliga och det bottenlösa. Tankar om konst och humaniora tillägnade Margaretha Rossholm Lagerlöf, red. Tomas Björk, Peter Gillgren m.fl., Stockholm 2010, s. 14ff.

22 Såsom applikationen i viss mån kommer att visa ingår flera av den augustinsk-lutherska diskurstypens komponenter i etablerade generiska arketexter, exempelvis klagosången, som på goda grunder kan betraktas en augustinisk-luthersk genre (jfr Karl Barth, Hiob, red. Helmut Gollwitzer, Neukirchen-Vluyn 1966, s. 43ff; Pesch, s. 943ff.; Hans-Joachim Kraus, Psalmen, Neukirchen 1960, s. 391); den augustinsk-lutherska diskurstypen generellt är dock ingen generisk arketext.

23 Jfr Augustinus De doctrina christiana 1,3,3 (PL 34,20); förf:s De civitate Dei 14,13 (PL 41,421); Henri de Lubac, Catholicisme. Les aspects sociaux du dogme, Paris 1983, s. $265 \mathrm{ff}$.; Christos Yannaras, Person und Eros. Eine Gegenüberstellung der Ontologie der griechischen Kirchenväter und der Existenzphilosophie des Westens, Göttingen 1982, s. 256ff.; Paul Evdokimov, Die Frau und das Heil der Welt, München 1960, s. 40f., 47; Alfred Adam, "Das Fortwirken des Manichäismus bei Augustin", Zeitschrift für Kirchengeschichte 66 (1958), s. 22ff.; Franz Pieper \& J.T. Mueller, Kristen dogmatik, Uppsala 1985, s. 554ff.

24 Jfr Johannes van Oort, "Civitas dei-terrena civitas. The Concept of the Two Antithetical Cities and Its Sources", i: Augustinus. De civitate Dei, red. Christoph Horn, Berlin 1997, s. 157ff.

25 Eberhard Jüngel, Zum Wesen des Friedens. Frieden als Kategorie theologischer Anthropologie, München 1983, s. 25ff.; Wilhelm Geerlings, "De civitate Dei XIX als Buch der Augustinischen Friedenslehre", i: Augustinus. De civitate Dei, s. 232. 
derar Augustinus att återföra varierande företeelser på ett enhetligt, generellt fenomen. ${ }^{26}$ För det andra sammanlänkas homogeniseringen med intensifiering och renodling. De separerade begreppen baseras inte på relativa värden eller statistiska genomsnittsfall utan ges en extrem, absolutifierad form. ${ }^{27}$ I De civitate Dei omformuleras den äldre liturgiska traditionens konkreta beteckning den onde till abstraktet det onda, som förstås som "summum malum", en veritabel ond princip. ${ }^{28}$ För det tredje slutligen tillåts inget tertium quid, inga sammansmältningar, inga korsningar och kompromisser mellan de enligt detta förfarande konstruerade begreppen. ${ }^{29}$ Medan de grekiska kyrkofäderna ofta framhäver mångtydiga ambivalenser och återför ett och samma fenomen på flera simultana orsaker, regleras de augustinsk-lutherska resonemangen av uteslutningens figur. ${ }^{30}$ Frälsningen sker, hävdar Luther, allena genom tron, uppenbarelsen finns allena i Bibeln. ${ }^{31}$ Även då de två teologerna introducerar inkluderande formler, tänker de innerst inne på ett exkluderande sätt. Augustinus karakteriserar visserligen männikosläktets aktuella läge som "en blandning" av civitas Dei och civitas terrena, men de båda civitates betraktas som lika åtskilda som människans goda och onda handlingar. ${ }^{32}$ Mellan de absolutifierade begreppen accepteras inga frizoner. ${ }^{33}$ Enligt Augustinus måste de som inte älskar Gud nödvändigtvis älska sig själva; för ett tredje alternativ ges inget teoretiskt utrymme. ${ }^{34}$ De båda teologerna realiserar sina tre begreppssäkrande strategier via rationellt-logiska operationer och förtydligande språkmarkörer. Resonemangen styrs av explanativa och kausala figurer. ${ }^{35}$ Disjunktiv samordning dominerar på de kopulativa relationernas bekostnad. ${ }^{36}$ De additiva uttryck som anlitas (simul, partim ... partim) överskyler i regel oförenliga alternativ. Luthers formel simul iustus et peccator markerar att människan är helt och hållet fördärvad och helt och hållet rättfärdig utan någon möjlig utjämning mellan de båda

26 Jfr John M. Rist, Augustine. Ancient thought baptized, Cambridge 1994, s. 217, 220f., 234, 310; Hermann Häring, Die Macht des Bösen. Das Erbe Augustins, Zürich 1979, 274f.; Otfried Höffe, "Positivismus plus Moralismus. Zu Augustinus' eschatologischer Staatstheorie”, i: Augustinus. De civitate Dei, s. $280 f f$.

27 Jfr Franz Georg Maier, Augustin und das antike Rom, Stuttgart-Köln 1955, s. 211; Rist, Augustine. s. 191ff., 259.

28 Augustinus, De civitate Dei 19,1 (PL 41,621); jfr Adam, ”Das Fortwirken”, s. 23.

29 Jfr Donald X. Burt, "Cain's City. Augustine's Reflections on the Origins of the Civil Society", i: Augustinus. De civitate Dei, s. 206; Geerlings, s. 216; John M. Rist, "Augustine on Free Will and Predestination", The Journal of Theological Studies 20 (1969), s. 440; förf:s Augustine, s. 198, 310; Henri-Irénée Marrou, Saint Augustin et la fin de la culture antique, Paris 1938, s. 341.

30 Jfr Peter Nagel, Die Motivierung der Askese in der alten Kirche und der Ursprung des Mönchtums, Berlin 1966, s. 62ff.; Evdokimov, s. 99, 103; Flasch, "Logik", s. 47f.; Pieper \& Mueller, s. 428f.

31 Jfr Ricardo J. Quinones, Dualisms. Agons of the Modern World, Toronto 2007, s. 87; Pieper \& Mueller, s. 73ff., 427f., 432ff.

32 Augustinus, De civitate Dei 15,22 (PL 41,467); jfr förf:s Enarrationes in Psalmos 61,6ff. (PL 36,733ff.); Maier, s. 162; Robert A. Markus, Saeculum. History and Society in the Theology of St Augustine, Cambridge 1970, s. 98.

33 Jfr Rist, Augustine, s. 310; Häring, s. 215; Burt, s. 206; Kurt Flasch, "Streitfragen", i: Logik des Schreckens, s. 265ff.; förf:s "Logik", s. 47f.

34 Jfr Augustinus, De civitate Dei 14,28 (PL 41,436); Rist, Augustine, s. 310f.; Julius Gross, Geschichte des Erbsündendogmas. Ein Beitrag zur Geschichte des Problems vom Ursprung des Übels, München-Basel 1960ff., I, s. 355f.

35 Jfr Kurt Flasch, "Nachwort”, i: Logik des Schreckens, s. 312, 328; förf:s "Logik”, s. 61f.; Paul Ricœur, Le conflit des interprétations. Essais d’herméneutique, Paris 1969, s. 266, 276f.; förf:s Le Mal. Un défi à la philosphie et à la théologie, Genève 2004, s. 29ff., 34.

36 Jfr Rist, Augustine, s. 311; Flasch, "Streitfragen", s. 265f.; Paul Althaus, Die Theologie Martin Luthers, Gütersloh 1962, s. 112. 
kvaliteterna. ${ }^{37}$ En strategisk roll tilldelas logiskt fokuserande, särskiljande och avgränsande ord som exempelvis Luthers många solae: "sola scriptura", "sola fide" och "sola gratia" ${ }^{38}$

Ett dominerande drag i Trotzigreceptionen har varit en prioritering av den syntetiska linjen i författarskapet. I det lysande mörkret lyder titeln på den första akademiska avhandlingen ägnad Trotzigs oeuvre. ${ }^{39}$ Samma syntetiska tolkningsschema präglar många recensenters och forskares förståelse av Dykungens dotter. Vanliga i deras läsningar är sammanförandets och inklusionens uttryck: "hybrid", "förblandning", "sammansmältning", "samhörighet", "samstämdhet", "mötesplats" etc. ${ }^{40}$ Romanens skrivsätt genomsyras av, heter det i en typisk formulering, "en strävan att föra sammman, bryta ner gränser och beskriva en totalitet". ${ }^{41}$ Trotzig själv har upprepade gånger intygat att hon vid sidan av sin syntetiska ambition företräder en analytisk hållning. I sina artiklar artikulerar hon ett behov av "särskiljanden" med bas i "en obeveklig gräns, en absolut väsensskillnad".42 En verklighetsbeskrivning "där allt går runt på samma plan, där betydelser inte kan urskiljas" avvisas som ett i längden ohållbart alternativ. ${ }^{43}$ Dykungens dotter följer i långa stycken detta särskiljandets program. De flesta analytiska grepp som Augustinus och Luther sätter i spel i sina texter är också högst verksamma i Trotzigs roman. Berättaren visar en stor förkärlek för distinktioner och tenderar att ordna diegesen i tydliga sfärer och typer. Flickans verklighet utgörs av dagens normala liv och "det andra livet, det underliga andra landet" (230). ${ }^{44}$ Människokropparna liknar antingen slott eller fängelser (115). Samhället består av domarna och de dömda (186). Även då romanen tematiserar en svåröverskådlig mångfald, blir denna så småningom indelad i mer distinkta grupper. Skolbarnen på skolgården liknar visserligen "en bisvärm" (151), som ägnar sig åt allehanda sysslor, men tilldelas med tiden klart åtskilda roller i historien "om starkast och svagast" (152). Berättaren nöjer sig inte med att arrangera verkligheten utifrån en rad avgränsade kategorier utan studerar också själva separeringsakten. Gården sjunger "lycklig och odelad" (121) för att strax därefter dela sig i bödlarna och "den som" (122). Läroverkets "[d]ystra lärare" sorterar eleverna i "de livsdugliga" och ett "i verkligheten utdömt material" (150). Frekventa i romanen är verb som betecknar delande: dela (16), dela upp (52), skilja åt (140), sära (225) etc. Berättaren är noggrann med att införliva diegesens olika komponenter -

37 Jfr Augustinus, De duabus animabus 10,14 (PL 42,194); Ulrich Duchrow, Christenheit und Verantwortung. Traditionsgeschichte und systematische Struktur der Zweireichenlehre, Stuttgart 1970, s. 466f.; Alfred Adam, Lehrbuch der Dogmengeschichte, Gütersloh 1965ff., II, s. 210f., 242, 319; Wilfried Joest, Gesetz und Freiheit. Das Problem des Tertius usus legis bei Luther und die neutestamentliche Parainese, Göttingen 1956, s. 57ff.

38 Jfr Augustinus, De diversis quaestionibus 1,17 (PL 40,121), 1,22 (PL 40,128); Adam, Lehrbuch, II, s. 192, 314, 326; Pieper \& Mueller, s. $73 \mathrm{ff}$.

39 Ulf Olsson, I det lysande mörkret. En läsning av Birgitta Trotzigs De utsatta, Stockholm 1988.

40 Helen Andersson, "Litteratur som virtuell verklighet och drömvision - exemplet Dykungens dotter", i: Mediekulturer. Hybrider och förvandlingar, red. Claes-Göran Holmberg \& Jan Svensson, Stockholm 2004, s. 26; Pär-Yngve Andersson, Överskridandets strategier. Lyrisk romankonst och dess uttryck hos Rosendahl, Trotzig och Lillpers, Örebro 2004, s. 165, 165, 167, 169; Eva Ström, ”Den inre orten", Sydsvenska Dagbladet 28.8.1988.

41 Andersson, Överskridandets strategier, s. 167.

42 Birgitta Trotzig, "Tankens arbetare har i vårt århundrades mörker en uppgift - att skilja dödsprincip från livsprincip", Expressen 9.3.1981; förf:s "Vi håller på att vakna", Aftonbladet 27.9.1987.

43 Birgitta Trotzig, "Det outhärdliga får inte glömmas", Dagens Nyheter 17.4.1983.

44 Sidhänvisningarna inom parentes i löptexten åsyftar romanens första utgåva: Birgitta Trotzig, Dykungens dotter. En barnhistoria, Stockholm 1985. 
både gestalter och föremål - i de på så sätt konstituerade klasserna. Flickan exempelvis är "en av de lägre" (186), "en av de glada" (230), en "av den sorten som bara strålar" (56).

Romanens bärande kategorier tryggas via mekanismer som leder tanken till Augustinus och Luthers värdetyranni. För det första konsolideras de urskilda grupperna genom en energisk intern homogenisering. Det diegetiska samhällslivets skilda institutioner - skolan, kasernen, fabriken, fängelset - förenas i bilden av "en labyrint så utformad att den skulle bilda kroppsform åt själen" (149). För det andra underkastas de på så vis homogeniserade klasserna en intensifiering och absolutifierande renodling. Berättaren nöjer sig inte med att förena barnens "många röster" (89) till bara "en" (89) röst utan låter den också vara "[k]lar som vatten" (89) och representera "den onde anden" (93). På ett motsvarande sätt stegras tystnaden till "stentystnad" (164), "dödstystnad" (151), "den bottenlösa istystnaden" (164). Renodlingen förstärks ytterligare genom markörer som antyder fenomenens bestående natur: "bergfast" (251), "orubblig" (238), "en och samma" (74), "oavlåtligt" (74), "ständigt" (142).

Även den tredje av Augustinus begreppssäkrande strategier, uteslutning, är fullt verksam i Dykungens dotter. Berättaren låter inte sina homogeniserade och absolutifierade kategorier sammansmälta med några andra kvaliteter. I Mojan finns "bara ett tomt hål" (68). Maskinerna arbetar "på absolut bara ett sätt" (74). Dödstystnaden vilar "allenahärskande över området" (192). Romantexten rymmer visserligen inkluderande formler, men de döljer i regel ett exkluderande tänkande. Flickan tillhör "till hälften" (230) en normal, till hälften "en underlig värld" (230), men de kategorier som sammanblandas riktigt vs underligt, mörker vs ljus, ont vs gott - påverkas knappast av det syntetiska skrivsättet: "ont och gott var kvar som vanligt" (202). Trogen sin värdetyranniska attityd är berättaren obenägen att i romanens dieges tillåta något ingenmansland, några mellanstationer. Inte ett enda barn på gården får förhålla sig neutralt till flickan: "allesammans" (123) vänder de sig "mot henne" (123), "till och med de riktigt små" (93) tar på sig bödlarnas roll och "piper med på sitt vis" (93). Handlingen förläggs visserligen till "de främmande mellantrakterna" (185), men de beskrivs i exkluderande termer som en kombination av i grunden oförenliga positioner. Romanens samhällsordning exempelvis består av dem som "var över" (186) och dem som "låg under" (186) - någon mellanklass ges inte existensberättigande.

De kategorisäkrande strategierna realiseras med hjälp av typiska rationellt-logiska medel. Särskiljandet genomförs via etablerade klassifikationsbeteckningar - "art" (201), "sort" (59, 156), "klass" (150), "slag" (79) - och via den filosofiska kategorilärans klassiska parametrar, som explicit kan omnämnas i romantexten: "tillstånd" (221), "material" (132), "plats" (201), "förhållande" (149), "orsak" (187), "Tillhörighet" (89), "egenskap" (150). Vanlig är en abstraherande omskrivning av konkreta attribut, ett grepp med renodlande, absolutiserande effekt. Ogenomträngliga grenar blir till "en ogenomtränglighet av grenar" (71). Efter samma nominaliserande mönster skapas "fullgångenhet" (143), "gråhet" (136), "fulhet" (92), "formlöshet" (156), "förnekande" (9), "det elaka" (92), "det orörliga" (197). Distinktionerna framhävs genom frekvent anlitad disjunktiv samordning, som först och främst realiseras genom konjunktionen eller: "historien om pojke eller flicka" (152), "värderat - uppåt! - eller avfärdat - neråt!" (150). En liknande roll får romanens talrika pronomen och adverbial med särskiljande funktion som "somliga" ... "andra" (115), "åt ena hållet" ... "åt andra hållet" (13), "den ena" ... "den andra" (19). 
Många av romanens kopulativa konjunktioner och adverb döljer en disjunktiv betydelse. Formeln "äta och ätas" (121) görs synonym med "äta eller ätas" (60). Enligt samma logik består staden visserligen av "dem som dömde och dem som blev dömda" (25), men för den enskilda invånaren är denna additivitet likvärdig med disjunktivitet: man är antingen den som "bestämde" (186) eller den som "bestämdes över" (186). Ibland blir de kopulativa relationerna explicit ifrågasatta av berättaren: "Inte kan man leva och både glömma och minnas?" (43). En viktig plats bland de renodlande och exkluderande manövrerna intar berättarens starkt fokuserande skrivsätt. En hög frekvens i texten uppvisar adjektivet fullkomlig och adverbet fullkomligt - "fullkomlig överskådlighet" (149), "fullkomlig ensamhet" (145), "fullkomligt tyst" (272) - som ackompanjeras av ett helt spektrum av ekvivalenta uttryck: "fullständig" (125), "absolut" (74), "alldeles" (14), "helt" (171), "helt och hållet" (14), "alltigenom" (82), "riktigt" (123). En intensifierande effekt får också ett flitigt bruk av superlativ: "den yttersta makten" (201), "svartaste midvinternatt" (211), "i övergivnaste mörkret" (211). Mycket vanliga i romanen är logiskt fokuserande pronomen och adverb: "enda" (36), "bara" (65), "enbart" (118), "endast" (186), "egen" (224), "just" (210), "till och med" (50), "själv" (96), "åtminstone" (228), "särskilt" (68). En exkluderande funktion tilldelas också olika typer av negativa uttryck: varken ... eller (65), ingen (165), "ingenting annat än" (80), aldrig (67).

Kristna tankeparadigm med syntetisk inriktning bygger i regel sin argumentation kring plurala kategorier. ${ }^{45}$ Augustinus däremot resonerar snarare i singulära banor. Som ett barn av romarnas juridisk-etiska tradition ser han som antropologins självklara undersökningsobjekt en separat agent utrustad med egen viljefrihet och eget ansvar. ${ }^{46}$ Sitt absolutifierade värdesystem konstruerar han inte för att normera samhällets offentliga praxis utan för att skärskåda den enskilda människan och hennes privata sfär. ${ }^{47} \mathrm{Med}$ an syntetiskt orienterade teologer ger företräde åt korporativa föreställningar, omtalar Augustinus i definitionssammanhang sina centrala operativa begrepp - själ, ande, förnuft, minne, kropp - i ental. ${ }^{48}$ Hans narration söker sig till individuella gestalter. Berättarens roll axlas av en profilerad jagröst som gärna framhäver sin singularitet. ${ }^{49}$ Enligt samma linje gör Luther en enskild troende till rättfärdighetslärans medelpunkt. ${ }^{50}$ Tydlig hos de båda tänkarna är tendensen att underkasta kollektiv en långtgående singularisering. Mänskligheten återförs på Adam, världsstaden på hans son Kain. ${ }^{51}$ Plurala fenomen belyses via singulära begreppskonstruktioner. De olika böjelserna och strävandena översätts till en enda voluntas, de enskilda synderna till arvsynden. ${ }^{52}$ Då större kollektiv

45 Jfr Nicolas von Arseniew, Ostkirche und Mystik, München 1925, s. 29f.; de Lubac, s. 301ff.; Friedrich Heiler, Die Ostkirchen, München-Basel 1971, s. 91ff., 132ff., 429.

46 Jfr Gisbert Greshake, Geschenkte Freiheit. Einführung in die Gnadenlehre, Freiburg 1977, s. 39ff., 50; Albrecht Dihle, The Theory of Will in Classical Antiquity, Berkeley 1982, s. 132ff.; Höffe, s. 281; de Lubac, s. 265ff.

47 Jfr Rist, Augustine, s. 198, 232.

48 Jfr Augustinus, De trinitate 14,14,20f. (PL 42,1051f.); förf:s De civitate Dei 12,24 (PL 41,373f.); Gerard O'Daly, Augustine's Philosophy of Mind, London 1987, s. $7 \mathrm{ff}$.

49 Jfr Augustinus, Confessiones 1,18,29 (PL 32,673f.); Kurt Flasch, Augustin. Einführung in sein Denken, Stuttgart 1980, s. 229ff.; Eugene TeSelle, Augustine the Theologian, London 1970, s. $189 \mathrm{ff}$.

50 Jfr Paul Hacker, Das Ich im Glauben bei Martin Luther, Graz 1966, s. 22ff., 34ff., 60ff.

51 Jfr Augustinus, De civitate Dei 14,1 (PL 41,403), 15,5 (PL 41,441); Leo Scheffczyk, Urstand, Fall und Erbsünde. Von der Schrift bis Augustinus, Freiburg/B 1981, s. 204ff.

52 Jfr Augustinus, De civitate Dei 14,4 (PL 41,407); 14,6ff. (PL 41,409ff.), Gross, I, s. 275ff.; Erich Dinkler, Die Anthropologie Augustins, Stuttgart 1934, s. 94, $117 \mathrm{ff}$. 
tematiseras får de genast ett distributivt förtydligande. "Guds folk" blir till "var och en av oss", "människosläktet" till "varje enskild". ${ }^{33}$ Narrativa inslag med människogrupper som aktörer kommenterar Augustinus i sina texter med hänvisning till en separat gruppmedlems beskaffenheter. I Confessiones är det visserligen flera "unga oduglingar" som stjäl päron, men historien utmynnar i en diskussion av en enskild själs "elakhet". ${ }^{4}$ Den breda framställningen av mänsklighetens historia i De civitate Dei får på ett motsvarande vis sitt djupaste facit i analysen av den enskildes kärlek och dess kvalitet. ${ }^{55}$

Dykungens dotter ansluter sig i stor utsträckning till Augustinus och Luthers singulära orientering. Romanens personbetecknande substantiv och pronomen används i regel i singularform och åsyftar enstaka individer: "han" (65), "kvinnan" (29), "den fullvuxna varelsen" (55), "främlingen" (65), "värdinnan" (52). Trots att berättaren ibland nämner ordet själ i plural $(47,272)$, dominerar singularuttrycken, som i regel refererar till en konkret, individuell själ: "hennes själ" (211), "hans rena själ" (184), "ur djupet av sin vänliga själ” (231). Även annan antropologisk vokabulär som aktualiseras i Dykungens dotter får vanligen beteckna ental: "människa" (22), "utanför-varelse" (231), "person" (81), "den andre" (111). Ett singulärt synsätt präglar också berättarens allegoriserande teknik. Majoriteten av de bilder som illustrerar människans existentiella villkor fokuserar individuella varelser: padda (22), svart fågel (165), "känseldjur" (38), sugdjur (43) etc. Redan i romanens första mening ger sig berättaren till känna som ett enskilt jag: "Jag har en historia att berätta” (7). Den singulära berättarrösten förblir synlig hela romanen igenom.

Dykungens dotter följer också på många plan en singulariserande rörelse och låter flertal övergå i ental. Trots att romanen gärna uppmärksammar större grupper, låter den aldrig den enskilde helt uppgå i massan. Textens kollektiva framställningssätt får ofta en distributiv precisering. Berättaren nöjer sig inte med att skildra de hemlösa i klump som "folk" (50) eller "matkö" (50) utan noterar också att "[v]ar och en satte sig långt från de andra" (50). Orörligheten på den rättspsykiatriska kliniken vilar inte bara "över allt och alla" (260) utan också "över var och en ensam" (260). En rad plurala element i diegesen skildras som singulära företeelser. Fabrikens komplicerade spolsystem framstår som "maskinen" (189), Mojans destruktiva handlingar förklaras med hennes "svarta sjukdom" (221). Kollektiv beskrivs med en enskild individ som modell. Gårdens barn blir till "den onde anden" (93), deras kroppar till "En kropp. Och en röst - många röster, men i alla fall bara som en" (89). Berättaren tar gärna avstamp i en hel människogrupp för att sedan övergå till en separat gestalt. Passagen om det tunga arbetet på fabriken börjar med att fixera "en morgontyst massa mödrar" (73) för att så småningom koncentrera sig på Mojan: "En i massan av kroppar var denna ogifta mor" (74). I samma veva avlöses pluralformer av singularformer: "celldörrarna" (34) av "Dörren" (34), "flickorna" (151) och "pojkarna" (151) av"denna flicka" (152). De relativt frekventa konstruktionerna en av och ett av får vanligen till uppgift att markera växlingen till ett individfokuserat skrivsätt: "I detta samhälle var flickan en av de lägre" (186).

Kristna tankeparadigm med plural inriktning konstruerar vanligen sin argumentering kring en externaliserande linje. Människan och hennes inre förklaras med hänvisning till hela kosmos dynamik; antropologin får aldrig någon autonom status utan infogas i ska-

53 Augustinus, Enarrationes in Psalmos 3,9f. (PL 36,77); förf:s De civitate Dei 14,1 (PL 41,403).

54 Augustinus, Confessiones 2,4,9 (PL 32,679).

55 Jfr Augustinus, De civitate Dei 14,6ff. (PL 41,409ff.), 14,28 (PL 41,436). 
pelseläran. ${ }^{56}$ Augustinus och Luther däremot ger sitt tänkande en internaliserande orientering. Den teologiska argumenteringen ställer antropologiska frågor i fokus och besvarar dem genom introspektion. ${ }^{57}$ Det inre betraktas som "människans medelpunkt" och sätts i direkt relation till Gud. ${ }^{58}$ Många av teologins fundamentala fenomen relateras till själen och dess komponenter. Synden och frälsningen härleds ur hjärtats viljeriktning. ${ }^{59}$ Sakramenten förankras i individens inre öppenhet för Guds ord. ${ }^{60}$ Begrepp som inte direkt låter sig förläggas i människans inre konstrueras efter mönster från själsliga processer. Relationerna inom treenigheten beskrivs i analogi med samspelet mellan förnuft, vilja och minne. ${ }^{61}$ Den sociala interaktionen belyses som en bild av den inre kärlekens kvalitet. ${ }^{62}$ En internaliserande rörelse reglerar inte bara förhållandet mellan det yttre och det inre utan också själens invärtes ordning. Inom minnets sfär sätts memoria interior högre än memoria exterior. ${ }^{63}$ På ett analogt sätt privilegieras sensus interior, visio interior, interior vis etc. Den paulinska homo interior åberopas som en central frälsningskategori. ${ }^{64}$ Utmärkande för den teologiska diskursen är ett flitigt bruk av internaliserande uttryck: in, intra, intrare, internus, interior, intus, introrsum, intimus, intrinsecus etc. ${ }^{65}$ En av deras vanligaste funktioner är att referera till människans mentala värld: "i mig själv", "inom oss", "Innerst i våra hjärtan". ${ }^{6}$ Många av denna sorts förinnerligande signaler förstärks med bildspråkliga medel: "i mitt hjärtas kammare", "i min inre boning", "i mitt minnes ofantliga hall". 67

Dykungens dotter uppvisar samma internaliserande tendens. Berättaren är genomgående intresserad av gestalternas inre liv och deras olika mentala processer: de tänker (138), förstår (221), uppfattar (253), begriper (219), minns (146), längtar (102), hoppas (138), känner "oro" (139), "häpnad" (269), "skam" (53). Romantexten är full av förinnerligande adverb: in, inne, innerst, invärtes, inåt, innanför, härinne, därinne, därinnanför etc. En av deras främsta uppgifter är att aktualisera människans själsliga sfär: "någonstans

56 Jfr Gisbert Greshake, Gnade als konkrete Freiheit. Eine Untersuchung zur Gnadenlehre des Pelagius, Mainz 1972, s. 187ff., 233; Vladimir Lossky, Die mystische Theologie der morgenländischen Kirche, Graz 1961, s. 116ff., 143f.; Scheffczyk, s. 123f.; Evdokimov, s. 77ff., 84.

57 Jfr Adolf von Harnack, Dogmengeschichte, Tübingen 1991, s. 292; Peter Schäfer, Das Schuldbewusstsein in den Confessiones des heiligen Augustinus. Eine religionspsychologische Studie, Würzburg 1930, s. 10; Pesch, s. 937, 947; TeSelle, s. 189ff.; Althaus, Die Theologie, s. 56ff.; Hacker, s. 28.

58 Augustinus, Enarrationes in Psalmos 108,32 (PL 37,1445), 141,3f. (PL 37,1834f.); Gareth B. Matthews, "Augustine's First-Person Perspective", i: Augustine and Philosophy, red. Phillip Cary m.fl., Lanham 2010, s. 42; Étienne Gilson, Introduction a l'étude de Saint Augustin, Paris 2003 s. 140; Greshake, Geschenkte Freiheit, s. 41; Hacker, s. 22ff., 185; Pesch, s. 456ff., 864ff., 935ff.

59 Jfr Gross, I, s. 298f.; Hacker, s. 106ff., 185, 213.

60 Jfr Ulrich Asendorf, Eschatologie bei Luther, Göttingen 1967, s. 91ff.; Althaus, Die Theologie, s. 300ff.; Pesch, s. 334ff., 793.

61 Jfr Flasch, Augustin, s. 342ff.; Lossky, s. 104f.

62 Jfr Augustinus, De civitate Dei 14,28 (PL 41,436); Erich Dinkler, "Augustins Geschichtsauffassung", Schweizer Monatshefte 34 (1954), s. 521.

63 Jfr Augustinus, De trinitate 14,6,8 (PL 42,1041f.); Flasch, Augustin, s. 344ff., 350ff.

64 Jfr Augustinus, Confessiones 7,17,23 (PL 32,745), 8,5,12 (PL 32,754); förf:s De trinitate 11,3,6f. (PL 42,988f.); O’Daly, s. 90f., 102ff., 175. Augustinus homo interior hänvisar till Rom 7:22.

65 Augustinus, Confessiones 10,8,13 (PL 32,785), 10,9,15 (PL 32,785), 10.40,65 (PL 32,807); förf:s De trinitate 10,5,7 (PL 42,977), 10,8,11 (PL 42,979), 11,7,11 (PL 42,993). Jfr Kenneth Burke, The Rhetoric of Religion. Studies on Logology, Berkeley 1970, s. $57 \mathrm{f}$.

66 Augustinus, Confessiones 4,12,18 (PL 32,701), 6,11,20 (PL 32,729); förf:s Contra Julianum 2,3,7 (PL 44,677).

67 Augustinus, Confessiones 8,8,19 (PL 32,757), 10,8,14 (PL 32,785). 
inne i honom" (164), "djupt inne i henne" (194), "därinne i henne" (8). I sin internaliserande funktion får de hjälp dels av prepositionsfraser av typen "i henne" (103), "inom varje vuxen" (89), dels av olika sorters substantiveringar som "i sitt innersta" (59), dels av fraser med det förstärkande pronomenet själv, exempelvis "i mig själv" (162), dels av partikelverb med in: lysa in (61), föra in (103), se in (55), dels av partikelbaserade particip och adjektiv: "inåtvänd" (174), "innesluten" (246). Romanens framställningar av gestalternas mentala värld upptar stort utrymme och aktiverar ett helt spektrum av avancerade diskursiva strategier som logiska operationer (distinktion, deduktion, induktion, syllogism, verifikation), retoriska figurer (amplifikation, upprepning, retorisk fråga, hyperbol, ironi, exklamation, conciliatio, evidentia, expolitio, regressio, interpositio) och metaforiska bildsekvenser som associerar till djup (194), botten (183), kista (97), bur (206).

Påfallande ofta privilegierar berättaren det inre gentemot det yttre. "Det yttre ljuset" (109) görs beroende av ljuset "inuti" (109) gårdskarlen, "den yttre människan" (80) beskrivs som mindre sann än "den inre" (80). En förinnerligande transformering underkastas många av diegesens betydelsebärande element. Stjärnorna slocknar inte "i sig själva" (159) utan "inuti" (109) gårdskarlen, bortstöttheten sitter "inuti" (50) de arbetslösa, fängelset ligger i Mojans "stora huvud" (223). Berättaren nöjer sig inte med att projicera yttre objekt i gestalternas inre utan införlivar dem också i deras konkreta mentala aktiviteter: tankar, vakendrömmar, varseblivningar etc. Lukten sitter fast i arbetarnas "egna luktsinnen" (190), nattlandskapet fyller gårdskarlens "minne" (179) och lever "[b]akom hans ögonlock" (179), Mojan gör sitt lilla barn till "en dröm som vävde sig in i hennes egna vävnader" (59). Fenomen som inte låter sig underkastas en så radikal internalisering underordnas det inre livets lagar. Eftersom det härskar "blek död" (68) i Mojans inre, blir även yttervärldens ljus "isigt kritigt" (68). Berättarens narration rör sig ofta från det yttre till det inre. Framställningen av Yllans maskinsystem övergår i en skildring av ackordsarbetarnas mentala förödelse (73ff.). Diegesens yttre fenomen och historiens tilldragelser förklaras kontinuerligt genom inre processer. Föräldrarna på gården orkar inte med sina barn, eftersom det "inom varje vuxen gnagde och grät och stormade en sådan arvfiende, ett sådant outhärdligt barn" (89).

Kristna tankeparadigm med externaliserande tendens konstruerar i regel sin teologiska diskurs ur fågelperspektivet. Deras metod är att betrakta tillvaron "de haut et de loin", så att inget som är "local, individuel, fragmentaire" skymmer de övergripande frälsningssammanhangen. ${ }^{68}$ För Augustinus och Luther är detta vida, sublima betraktelsesätt problematiskt. Syndens negativa inverkan på människans inre förmågor är, menar de, så irreparabelt att den också måste lämna spår i den teologiska framställningens optik. ${ }^{69}$ De båda tänkarna tar starka intryck av den gammaltestamentliga klagosångens berättarteknik och manifesterar sin hamartiocentriska grundhållning via tre strategier med

68 Pierre Teilhard de Chardin, Lavenir de l'homme, Paris 1959, s. 25; förf:s Le cœur de la matière, Paris 1976, s. 88; Lilli Sertorius, "Ortodoxe Theologie im 20. Jahrhundert", i: Bilanz der Theologie im 20. Jahrhundert. Perspektiven, Strömungen, Motive in der christlichen und nichtchristlichen Welt, red. Herbert Vorglimler \& Robert vander Gucht, Freiburg/B 1969f., II, s. 166, 177ff.; Pesch, s. 931ff., 944; Evdokimov, s. 40.

69 Jfr Gillian R. Evans, Augustine on Evil, Cambridge 1982, s. 36ff.; Gross, I, s. 357ff., IV, s. 29; Pesch, s. 938ff.; 956ff.; Duchrow, s. 209; Barth, s. 103f.; Reinhold Seeberg, Lehrbuch der Dogmengeschichte, Basel-Stuttgart 1960, IV/1, s. 205, 207. 
koppling till narrativt modus. ${ }^{70}$ För det första konstruerar de sin bild av varat utifrån ett grodperspektiv. ${ }^{71}$ På samma sätt som det klagande jaget i Ps 69 befinner sig "i djupa vatten" där "ingen botten är", placeras berättaren i Confessiones "i avgrundens djup".72 För det andra förser såväl Augustinus som Luther denna spatiala position med en fokaliseringsaspekt. Gud, skapelsen, frälsningsskeendet belyses ur den skuldtyngde troendes synvinkel. ${ }^{73}$ Enligt kyrkofadern styrs alla våra varseblivningsfunktioner - och i synnerhet seendet - av den syndkorrumperade viljan. Hans autodiegetiska berättare går inte fri från denna kognitiva begränsning. Allt han förnimmer och återger relativiseras av "ögonens villfarelser" och hjärtats "nertyngande lidanden". ${ }^{74}$ För det tredje slutligen tillämpar de två teologerna liten narrativ distans. ${ }^{75}$ I Augustinus antropologi beskrivs den svaga viljan som ett "lim" som fäster den syndiga människans uppmärksamhet vid yttervärldens "bråte". ${ }^{16}$ Samtidigt som hon befinner sig "långt borta från" Herren, dras hennes av nyfikenhet drivna blick till "många föraktligt betydelselösa ting" som nära omsluter den med sina lockande smekningar. ${ }^{77}$

De tre modusrelaterade strategierna är också verksamma i Dykungens dotter. Med utgångspunkt i inledningsscenens bild av "skaparen i avgrunden" (7) försöker Anders Tyrberg ordna romanens narrativa rörelse längs en linje utstakad av "polerna 'häruppe - därnere'" med människan "'häruppe"' och den gudomliga skaparen något "överraskande" placerad "'därnere". 78 Men den för de syntetiska tankeparadigmen karaktäristiska placeringen av skaparen i skapelsens djup ${ }^{79}$ styr de facto enbart i en begränsad grad berättelsens modus i Trotzigs verk. Minst lika viktigt för romanens optik är grodperspektivets omkastade härnere vs däruppe. Berättaren använder återkommande adverbet härnere och placerar sin observationspunkt "härnere på botten" (104), härnere "i parken i snösmältan" (198), "härnere" (54) i "egen upplösning" (54). En likartad perspektivering skapas av andra deixis-baserade uttryck (här/här-), som kopplas till adverbiala prepositionsfraser med låg situering: "här i graven" (260), "härinne i snårdjupet" (104), "härute" (26) på "gammal sjöbotten" (26) etc. Berättaren fokuserar ofta föremål som tillhör den

70 Jfr Kraus, s. XLVff., 481f.; Martin Luther, Dictata super Psalterium 68 (WA 3,421); Notger Slenczka, "Luther's Anthropology", i: The Oxford Handbook of Martin Luther's Theology, red. Robert Kolb m.fl., Oxford 2014, s. 215.

71 Jfr Edmund Schlink, "Gesetz und Evangelium als kontroverstheologisches Problem", Kerygma und Dogma 3 (1961), s. 24ff.; Albrecht Peters, Glaube und Werk. Luthers Rechtfertigungslehre im Lichte der Heiligen Schrift, Berlin-Hamburg 1962, s. 10ff., 79ff., 262ff.; Pesch, s. 932ff.

72 Ps 69:3; Augustinus, Confessiones 1,18,28 (PL 32,673), 2,4,9 (PL 32,679).

73 Jfr Otto Hermann Pesch \& Albrecht Peters, Einführung in die Lehre von Gnade und Rechtfertigung, Darmstadt 1981, s. 16ff., 41; Gerhard Ebeling, Luther. Einführung in sein Denken, Tübingen 1965, s. 29ff.; Pesch, s. 239ff., 456ff., 864ff, 935ff.

74 Augustinus, Confessiones 10,34,52 266 (PL 32,801), 10,40,65 (PL 32,807); TeSelle, s. 191ff.; O’Daly, s. 93.

75 Jfr Pesch, s. 932ff.; Schlink, s. 24ff.; Peters, s. 10f., 79ff., 262ff.

76 Augustinus, De trinitate 10,8,11 (PL 42,979); förf:s Confessiones 10,30,42 (PL 32,797), 10,35,57 (PL 32,803); Marrou, s. 350ff.

77 Augustinus, Confessiones 1,18,28 (PL 32,673), 10,34,51ff. (PL 32,800ff.), 10,35,57 (PL 32,803); André Labhardt, "Curiositas", i: Augustinus-Lexikon, red. Cornelius Mayer, Basel 1986ff., II, s. 188.

78 Anders Tyrberg, Anrop och ansvar. Berättarkonst och etik hos Lars Ahlin, Göran Tunström, Birgitta Trotzig, Torgny Lindgren, Stockholm 2002, s. 239. Jfr ibid., s. 210, 248ff., $265 \mathrm{ff}$.

79 Jfr Ignacio Escribano-Alberca, Glaube und Gotteserkenntnis in der Schrift und Patristik, Freiburg/B 1974, s. 90ff.; Pierre Teilhard de Chardin, Comment je crois, Paris 1969, s. 107, 158f., 211; förf:s Le cœur, s. 50ff., $145 \mathrm{ff}$. 
låga sfären - dy (11), slätt (20), sankmark (25), rötter (205), kärrvatten (37), pölar (118), å (76) - och beskriver dem med en påtaglig konkretion, medan den höga sfärens rekvisita (himmel, tak, sol) skildras som avlägsna och nästan osynliga. Denna kontrast i förening med andra positionerande markörer (prepositionsfraser, distansreglerande adverbial, visuella deformationer) skapar ett intryck av att observatören finns nere vid marken och tittar upp. I många fall blir den låga observationspunkten och det uppåtriktade seendet explicit tematiserade i texten. Illustrativ är framställningen av morgonen efter gårdskarlens kolosförgiftningsolycka:

När han vaknade nästa gång var taket bortlyft. Han låg och såg rakt upp i en svartblå himmel, rått skarpt solljus sken och dansade överallt. Fönster och dörrar blåste och slog. Allt var uppbruset, skändat. Han låg ute på gatan, isig sörjig jord, vattenpölarna stod under is. (117f.)

En annan av romanens frekvent använda modusstrategier är intern fokalisering. ${ }^{80}$ I citatet ovan legitimeras den låga observationspunkten av gårdskarlens diegetiska placering, som ger berättelsen en internt fokaliserad karaktär. Med samma motivering anlitas grodperspektivet även på många andra ställen i Dykungens dotter. Berättaren övertar inte bara gestalternas spatiala situering utan också deras intryck av den varseblivna världen. Att romanens städer genomgående kopplas till hyperboliserande adjektiv - "stor" (45), "jättestor" (25), "jättelik" (49), "väldig" (279) - motiveras av fokalisatorn Mojans förindustriella perceptionsmönster. Berättaren fokaliserar narrationen genom värdeladdade adjektiv ("förfärlig" (272), "främmande" (49), "tungt" (43)), genom förnimmelse- och fenomenverb (förefalla (49), synas (49), tyckas (50), verka (141)), genom bildspråkliga strategier som förvandlar skolgården till en öken (150), gör natten ensam (272) och låter lasarettet bli "ett land av is" (145), för att nämna bara några av textens otaliga synvinkelmarkerande medel.

Gårdskarlen berättar för sin dotter och styvdotter att stjärnorna en efter en försvunnit för hans syn och att han numera bara kan "'se saker på nära håll'” (159). Medan oskyldiga barn, påstår han, förmår skåda "'genom Guds öga"' (158), ser han endast det närmast befintliga och mest påtagliga: vårfärilar, "'Larver och puppor'” (159). Mycket av gårdskarlens närsynthet kan också återfinnas hos den extradiegetiska berättaren, som genomgående arbetar med olika typer av distansminskande medel. Romanen tar gärna avstamp i ett bredare synfält för att alltmer zooma in narrationens egentliga objekt. ${ }^{81}$ Framställningen av staden i järnvinterns grepp avlöses av en närbild av Veras dödskamp (153f, 160). Distansreduktionen kan ibland explicit verbaliseras i berättelsen: de fixerade föremålen syns "på håll knappt alls" (25), "nalkas" (109), "närmar sig, närmar sig" (169), blir "tydligare och tydligare" (225), tränger "in i näsa, mun, hals" (51). Men vanligen markeras den minskade distansen med implicita medel som bland annat ett frekvent bruk av adverbialen här och $n u$, det simultana berättandets presensformer och berättel-

80 Fokalisering som narrativ figur i Trotzigs författarskap diskuteras bl.a. i Olsson, s. 202ff., 213; Tyrberg, s. 228, 262; Mattias Pirholt, Ett språk, ett spår. En studie i Birgitta Trotzigs författarskap, Stockholm-Stehag 2005, s. 205; Bak, Den intersubjektiva synden, s. 118, 218f., 223; förf:s "Den kluvna kärnan. Läsningar av Birgitta Trotzigs 'Ormflickan'", Acta Universitatis Carolinae. Philologica. Germanistica Pragensia 21 (2012), s. 109.

81 Greppet diskuteras i Boris Uspenskij, A Poetics of Composition. The Structure of the Artistic Text and Typology of a Compositional Form, Berkeley 1973, s. 149. 
sens sceniska inslag. ${ }^{82}$ En viktig distansreducerande funktion fyller de många detaljer berättaren placerar i historiens dieges. De sammanförs ofta i långa enumeratio-fraser som ger narrationen en verklighetsnära påtaglighet: "nässlor, järnskrot, rostiga oljefat" (20), "balsaminer i köksfönstret, träsmattor på golvet, trådgardiner" (80). De flesta av dessa element spelar rollen av mimesiskonnotatörer, som inte driver intrigen framåt utan endast är till för att minska den narrativa distansen. Påfallande är att berättaren gärna uppehåller sig vid riktigt små föremål som endast är synliga på mycket nära håll: "mjuka grå nattflyvingar" (206), "flyn och mygg" (205), cementgolvets sprickor (76). Ett ofta anlitat distansminskande grepp i romanen är optisk deformation. Den i texten vanliga hyperboliseringen har till uppgift inte bara att styrka fokaliseringen utan också att signalera att det förstorade objektet betraktas på extremt nära håll. Fängelsemuren framstår som "väldig" (48), eftersom Mojan står "tätt intill" (48) den. I många fall antyds det reducerade avståndet mellan fokalisatorn och diegesen genom konturupplösning. Då den inspärrade dykungen rasar runt i sin cell och hans "näsa och mun skrapas mot väggen" (38), förnimmer han sitt "mörkrum" (27) på ett odifferentierat sätt som "[v]äggar. Väggar. Mur. Mur" (28). På ett motsvarande vis framstår parken som "det vata vilda" (198), åkerfältet som "[b]ara fåror, snö, fåror, snö" (15), stadens instängande murar som en "labyrinthusmassa" (253). En annan vanlig teknik med distansminskande effekt är anhopningen av olika sinnesintryck. Berättaren inte bara ser utan också rör vid diegesens objekt, förnimmer deras lukt, hör deras ljud. Tingen är skarpa (38), klibbiga (24), hårdfrusna (161), vassa (151), mjuka (87), de luktar "jord, gyttja, bräckvatten, våt vass i dikena" (20).

Som Boris Uspenskij observerat kan berättaren minska den narrativa distansen genom att låna sina gestalters språkbruk. ${ }^{83}$ Den extradiegetiska berättaren i Dykungens dotter anammar inte bara de intradiegetiska gestalternas perception och affekter utan också deras tal. Relativt få av de intradiegetiska replikerna återges rapporterat. I stället får gestalternas talesätt direkt infiltrera den extradiegetiska berättelsen. Berättaren låter flickans eget dialektala uttryck "Mou-ii-jan" (81) bilda stommen till den extradiegetiska narrationens egennamn "Mojan" (81). Gårdskarlens dramatiska fråga "'Varför låter du sparvarna falla till marken?"” (175f), hans episka formel "'Så gick åren"” (158), flickans inre rop "Ensam! Ensam!" (226) återkommer i ordagrann eller lätt modifierad form i den extradiegetiska berättelsen $(12,179,155,272,211)$. Romanens talrika partier i fri indirekt stil sammanför berättarens och gestalternas talesätt utan att en entydig skiljelinje mellan dem kan dras. ${ }^{84}$ Då berättaren exempelvis skildrar Mojans drömmar om fast arbete (54), hennes jubel över nyanställningen på Yllan (69) eller hennes negativa inställning till sötsaker (251) har man en känsla av att man hör hennes egen röst.

Medan kristna tankeparadigm med syntetisk orientering tenderar att bygga sin diskurs på likhets- och analogikategorin, omvandlar Augustinus och Luther kristendomen till - vilket den syntetiskt inriktade nyteologen Henri de Lubac kritiskt noterar - "une religion d'antithèses" ${ }^{85}$ En rörelse från likhet till motsats märks på de flesta plan i de

82 Jfr ibid., s. 58, 65ff., $113 \mathrm{ff}$.

83 Jfr ibid., s. 41, 52, 68, 132.

84 Jfr ibid., s. 32ff., 110ff.; Brian McHale, "Free Indirect Discourse. A Survey of Recent Accounts", PTL. A Journal for Descriptive Poetics and Theory of Literature 3 (1978), s. 249ff. Att fri indirekt stil i Trotzigs berättande prosa har en närhetsskapande effekt observeras i Pirholt, s. 259.

85 de Lubac, s. 138ff., 241ff., 273; Hans von Campenhausen, "Die Bilderfrage als theologisches Problem der alten Kirche", Zeitschrift für Theologie und Kirche 49 (1952), s. 45, 54ff.; Rist, Augustine, s. 276, 310; 
båda teologernas argumentering. Augustinus övertar från nyplatonismen en lång rad likhetsrelaterade kategorier - bild, skugga, spegling - men i stället för att med deras hjälp forma någon sorts "theory of the analogy of being" utnyttjar han dem i antitetiska syften. ${ }^{86}$ Luther låter Människosonen visa sig på jorden sub contrario och ser i korset snarare kontradiktionens än förlikningens symbol. ${ }^{87}$ Såväl Augustinus som Luther hanterar i regel de exkluderande distinktioner de konstruerar via sitt analytiska tänkesätt som antonymer. Typisk för de bådas resonemang är en reduktiv rörelse som inordnar en större grupp differenser under ett övergripande motsatspar. Luther ersätter skolastikens kategoriala nyansrikedom med några få enkla antonyma begrepp: lag vs evangelium, synd vs rättfärdighet, världsligt vs andligt rike etc. ${ }^{88}$ De båda teologerna försöker på olika vägar förstärka sina dikotomier. Dels tolkar de partikulära polariteter som manifestationer av mer generella oppositioner. Augustinus betraktar den bibliska antitesen Babylon vs Jerusalem som en symbolisk gestaltning av den principiella motsättningen mellan två universella stater: civitas terrena och civitas Dei ${ }^{89}$ Dels följer de två tänkarna sin internaliserande linje och förankrar yttre kontraster i mer fundamentala inre dualiteter. Kyrkofadern härleder sina två civitates ur två antitetiskt koncipierade kärlekstyper som bor i varje postadamitisk människosjäl. ${ }^{90}$ Dels radikaliserar både Augustinus och Luther sina oppositioner via intensifiering och renodling. I Confessiones skildras motsatsen mellan Gud och människans hjärta som en kontrast mellan den ljuvligaste saligheten och det bittraste eländet. Konkordieformeln gör skillnaden mellan människans ursprungliga och nuvarande natur "så stor som skillnaden mellan Guds verk och djävulens". 91 Intensifieringen realiseras ofta genom att en svag, privativ opposition mellan ett omarkerat och ett markerat led omvandlas till en stark, konträr opposition mellan två motsatt markerade led.92 Augustinus avvisar den neutrala "o-villigheten" som ett falskt koncept och ersätter den med en perverterad libido som kontrasteras mot Guds operativa vilja. ${ }^{93}$ Augustinus och Luthers antonyma tänkande påverkar direkt deras retorik och språk. ${ }^{94}$ Kyrkofadern hyllar antiteserna som "de vackraste bland talets prydnader" ${ }^{95}$ Hans texter är fyllda med

Markus, s. 45; Adam, "Das Fortwirken", s. 19; Dinkler, Die Anthropologie. s. 127ff.

86 Rist, Augustine, s. 259; jfr Johannes van Oort, "Civitas dei", s. 167; Franz Billicsich, Das Problem des Übels in der Philosophie des Abendlandes, Wien-Köln 1952ff., I, s. 226ff., 277; Flasch, "Logik", s. $110 \mathrm{f}$.

87 Jfr Bernhard Lohse, Martin Luther. Eine Einführung in sein Leben und sein Werk, München 1981, s. 155, 198ff.; Althaus, Die Theologie, s, 37, 40; Pesch, s. 148, 208.

88 Jfr Pesch \& Peters, s. 120; Althaus, Die Theologie, s. 218ff.; Ebeling, s. 194; Duchrow, s. 450, 466f.

89 Jfr Augustinus, De civitate 14,28 (PL 41,436); förf:s Enarrationes in Psalmos 61,6ff. (PL 36,753ff.), 136,1ff. (PL 37,1761ff.); Rist, Augustine, s. 234; TeSelle, s. 268ff.

90 Jfr Augustinus, De civitate Dei 15,1ff. (PL 41,437ff.); Johannes van Oort, Jerusalem and Babylon. A Study into Augustine's City of God and the Sources of His Doctrine of the Two Cities, Leiden 1991, s. 142ff.; Rist, Augustine, s. 155, 189f., 216; 234; Geerlings, s. 216.

91 Augustinus, Confessiones 8,3,8 (PL 32,752); Formula concordiae 1,1 (citerat i Hjalmar Lindroths översättning efter Svenska kyrkans bekännelseskrifter, Stockholm 1979, s. 501); Adolf von Harnack, Lehrbuch der Dogmengeschichte, Tübingen 1990, III, s. 64; förf:s Dogmengeschichte, s. 292; Markus, s. 45; Flasch, "Logik", s. 110.

92 Jfr John Peter Anton, Aristotle's Theory of Contrariety, London 1957, s. 79ff., 87ff.

93 Augustinus, De duabus animabus 1,10,14 (PL 42,104); Ragnar Holte, Beatitudo och sapientia. Augustinus och de antika filosofiskolornas diskussion om människans livsmål, Stockholm 1958, s. 245ff.; Flasch, Augustin, s. 209ff., 248.

94 Jfr Rist, Augustine, s. 310; Quinones, s. 87; Philip Ruge-Jones, Cross in Tentions. Luther's Theology of the Cross as Theologico-social Critique, Eugene 2008, s. $85 f$.

95 Augustinus, De civitate Dei 11,18 (PL 41,332). 
motsatsrelaterade satser, fraser ("boni et mali", "in vita et in morte") och ord (contra, contrarius, contradictio, adversus, oppositus, antitheta). ${ }^{96}$ Han använder gärna adversativa konjuktioner och adverb (vero, verum tamen, autem, sed, nihilominus) och låter dem uttrycka renodlade motsatsrelationer. ${ }^{97}$

Dykungens dotter speglar på många plan Augustinus och Luthers dikotomiserande tanke-och skrivsätt. Med antiteser laddas romanens hela diegetiska universum: den narrativa historiens rums- och tidsstrukturer, intrigföringen, gestaltkonstruktionen, samspelet mellan gestalterna och miljön etc. Länsfängelsets "råa benbyggnad" (25) kontrasteras mot "kyrkan" (25), "dödstiden" (272) mot "livstiden" (272), "den mörke" (101) mot "den goda människan" (146). Tydlig i texten är en rörelse från likhet till motsats. Berättaren konstaterar visserligen att flickan i parken möter "en som liknade" (197), men kursiveringen fungerar som en ironimarkör som antyder att den hon hittar i de flesta hänseenden bildar den eftersökta drömprinsens negativbild. Chockladfabriken vill likna paradiset, men visar sig vara "en pina" (228). Textens likhetsmetaforer - spår (275), spegling (197), eko (237), bild (199), återsken (202) - aktiverar antitetiska konnotationer. Lika signifikativ för Trotzigs roman är en rörelse från differens till motsats. Större delen av textens talrika åtskiljande distinktioner utvecklas till oppositioner. Barnen på gården liknar visserligen "alla sorters djur" (91) och utför "olika sorters rörelser: mjuka osäkra krypande, misslyckade tafatta milda" (91), men bakom denna pluralitet ligger en krass motsättning mellan "spindel" (92) och "offer" (93). Berättarens tendens att omvandla skillnader till motsatser framträder särskilt klart via den antonyma semantik som differensmarkörerna "annan" (251), "annorlunda" (252), "olika" (276), "dubbel" (43) får i texten. Flickans "andra sida" (79) preciseras som hennes destruktiva "vargsida" (123) i kontrast till hennes ljusa sida: den "strålande ömhet" (56) hon normalt bemöter världen med.

Berättaren använder olika medel för att förstärka sina dikotomier. En potentierande effekt har inte minst romanens internaliserande skrivsätt, som förankrar diegesens kontraster i gestalternas innersta kärna. Flickans motsägelsefulla beteende återförs på att hon är "delad i två" (106) i sitt inre. En annan motsatsradikaliserande manöver är universalisering. De arrangerade antiteserna genomsyrar "allt" (160), verkar "ständigt" (142), finns "inuti varje barn" (106), "inom varje vuxen" (89), "hos alla" (235). Ett vanligt dikotomiförstärkande medel i romanen är intensifiering. Oppositionen mellan fina och fula kroppar hyperboliseras till en kontrast mellan "skönhetens silkessammet" (115) och "ett fängelse vars slutna väggar närmar sig och stänger sig" (115). Romanens svaga, privativa motsatser laddas så starkt med semantisk substans att de glider över i starka dikotomier. I romanens skapelseberättelse (9) och inledningsscen (7ff.) utvecklas kontrasten mellan ljus och skugga, vara och icke-vara, till en opposition mellan två konträra krafter.

Romandiegesens dikotomiska orientering påverkar direkt språket. Berättaren har en påfallande förkärlek för antonymt konstruerade fraser: "förruttnelse och liv" (21), "Givaren och tagaren" (14), "sol och smuts" (122). De antitetiska substantivens plats kan övertas av verb, adjektiv, adverb och particip: "dog och återföddes" (21), "ont och gott" (202),

96 Augustinus, De civitate Dei 11,17ff. (PL 41,331ff.), 13,10 (PL 41,383), 15,5 (PL 41,442); förf:s Confessiones 9,2,3 (PL 32,764).

97 Augustinus, De civitate Dei 13,17 (PL 41,389), 14,2ff. (PL 41,404ff.); förf:s Confessiones 10,8,13 (PL $32,785)$. 
"fram och tillbaka" (90). Den syndetiska samordningens konjunktion och kan samtidigt avlösas av asyndetiska kopplingar med kommatecken, punkt, bindestreck, snedstreck eller utan skiljetecken: "vävs ut, vävs in" (70), "En dag. En natt" (58), "ville-ville inte" (224), "försvaret/angreppet" (267), "stigande sjunkande" (118). I linje med berättarens kontrastintensifierande tendens underkastas de antonyma fraserna olika hyperboliserande procedurer. De kan exempelvis kompletteras med förstärkande led ("starkt ljus och skugga" (217)), fördubblas ("tvinnades och sträcktes, delades och knöts" (73)) och utvidgas till långa parallelliserade satsradningar:

Staden håller ständigt på att brytas ner, förruttna. Ständigt byggs den upp, ständigt putsas sprickor, ständigt lagas fasader, ständigt faller den sönder igen. (142)

Den kontrastgenererande språkhanteringen manifesterar sig särskilt tydligt genom ett frekvent bruk av adversativa ord: "Men" (57), "däremot" (80), "dock" (259), "ändå" (42), "visserligen" (118), "i varje fall" (268), "i alla fall" (67). På ett likartat, dikotomiserande vis använder berättaren en lång rad andra bindeord - konjunktioner, subjunktioner, korrelativa adverb - som normalt inte behöver ange en motsättning: fast (175), eller (261), i och för sig (202), än ... än (169), hur .. än (115), vad ... än (66), på ett sätt .. på ett annat (179), ena sidan ... andra sidan (112).

I kristna tankeparadigm med syntetisk profil privilegieras de kontaktbaserade kategorierna delaktighet, genomträngning, sammankoppling, vävnad, kretslopp. ${ }^{98}$ Augustinus och Luthers diskurs däremot centreras kring olika typer av brott. Tydlig i de båda teologernas resonemang är en rörelse från kontinuitet till diskontinuitet. De civitate Dei nämner visserligen "en sorts sammanblandning" (permixtio, confusio) och "sammanväxande" (concretio) mellan Guds och den fallna människans rike men tillskriver denna förbindelse en ytlig karaktär och tolkar den som förtäckt oförenlighet. ${ }^{99}$ Det är huvudsakligen via tre bildsekvenser Augustinus och Luther konceptualiserar varats diskontinuiteter. Dels markerar de ett stort avstånd mellan sina kategorier. Avlägsenhetens vokabulär (longe, longinquus, remotus, absum) ges en strategisk plats i kyrkofaderns antropologiska argumentering. ${ }^{100}$ Dels blockerar Augustinus och Luther en naturlig kommunikation mellan elementen. De åberopar gärna bibelställen som inordnar varats komponenter i inkommensurabla system, åtskilda genom gränser, skiljeväggar, avgrunder. ${ }^{101}$ Hos Luther demonstrerar Kristus att klyftan mellan den syndiga människan och Gud har

98 Jfr Peter Schwanz, Imago Dei als christologisches Problem in der Geschichte der Alten Kirche von Paulus bis Clemens von Alexandrien, Halle 1970, s. 160f.; Hans Georg Thümmel, Bilderlehre und Bilderstreit. Arbeiten zur Auseinandersetzung über die Ikone und ihre Begründung vornehmlich im 8. und 9. Jahrhundert, Würzburg 1991, s. 44f.; Lossky, s. 87, 251f., 272; Yannaras, s. 63, 73, 150, 238ff.; Evdokimov, s. 103, 180f.; de Lubac, s. 244.

${ }^{99}$ Augustinus, De civitate Dei CD 15,8 (PL 41,446), 15,22 (PL 41,467); förf:s Enarrationes in Psalmos 51,6 (PL 36,604); Maier, s. 162; Markus, s. 98; Rist, "Augustine on Free Will", s. 424; Geerlings, s. 216.

100 Augustinus, Confessiones 2,2,2 (PL 32,676), 4,2,2 (PL 32,693), 4,14,21 (PL 32,702); förf:s Ad Simplicianum 1,2,16 (PL 40,120f.); jfr Rist, "Augustine on Free Will", s. 440.

101 Augustinus, Confessiones 1,18,28 (PL 32,673), 2,3,8 69 (PL 32,678), 4,10,15 (PL 32,700), 8,1,1 (PL 32,749), 10,2,2, (PL 32,770), 10,5,7 (PL 32,782); jfr Odilo Rottmanner, "Der Augustinismus. Eine dogmengeschichtliche Vorstudie”, i: förf:s Geistesfrüchte aus der Klosterzelle. Gesammelte Aufsätze, red. Rupert Jud, München 1908, s. 30; Rist, Augustine, s. 158f., 256, 264, 275f., 286; Dinkler, Die Anthropologie, s. 82ff., 88; Scheffczyk, s. 199ff.; Flasch, "Streitfragen", s. 265. Till de åberopade bibelställena hör 1 Kor 13:12, 2 Petr 2:4, Rom 11:33. 
en oöverbrygglig karaktär. ${ }^{102}$ Dels, slutligen, följer såväl Augustinus som Luthers tänkande "ein Konkurrenzmodell" och driver sina differenser till antagonismer. ${ }^{103}$ Typiskt för Augustinus antropologiska resonemang är ett flitigt bruk av martialisk vokabulär (bellum, rixa, tumultus, arma, militia, adversor). ${ }^{104}$ Luther talar enligt likartade linjer om fiendskap (hostis, odium, displicentia, inimicitia) mellan sina antitetiskt koncipierade instanser. ${ }^{105}$ De båda teologerna förstår de tre kontinuitetsbrytande bildkomplexen inte bara spatialt utan också temporalt och underordnar det historiska skeendet kvalitativa språng, som de inte försöker tona ner genom harmonierande manövrer utan belyser som något omstörtande, obotligt och oåterkalleligt. Det ögonblickliga framhävs på det durativas bekostnad. ${ }^{106}$ Såväl på rums- som tidsplanet underkastas brotten en långtgående universalisering och hyperbolisering. I Augustinus antropologiska resonemang är avståndet enormt, avgrunden ofantlig, mörkret allestädesnärvarande, kampen hetsig, fienden oövervinnerlig, fästningen ointaglig. ${ }^{107}$

Dykungens dotter delar på många plan Augustinus och Luthers fixering vid oöverkomliga brott. Romantexten rör sig i långa stycken från kontinuitet till diskontinuitet. Flickans epifaniska vision som låter solens strålar genomtränga materien som något "alldeles naturligt" (195) utmynnar i bilden av ljusets transcendens. Diegesens diskontinuiteter konkretiseras genom strategier med direkta motsvarigheter i Augustinus och Luthers diskurs. Dels markerar berättaren distans mellan verklighetens olika fenomen. Tingen placeras "långt bort" (236), skymtar "[v]id horisonten" (194), svävar "på andra sidan sjön" (168), ger "avlägset ljud" (48). Dels signaleras diegesens diskontinuiteter genom olika typer av skiljelinjer: "gränser" (121), "murar" (37), "befästningsvallar" (26), "väggar" (34), "brottytor" (38), "staket" (91), "galler" (34), "järngrindar" (45), "spärrar" (89), "dörrslussar" (264). Eftersom romanens värld är ett av Gud skapat vara, manifesterar sig diegetiska gränslinjer ofta genom varierande former av intet: "gap" (224), "svalg" (150), "spricka" (217), "ett tomt hål" (68). Dels ifrågasätts diegesens kontinuitet genom antagonisering. Relationer mellan romanvärldens komponenter beskrivs i termer av "strid" (264), "kamp" (221), "krig" (158), "slagsmål" (151), "bråk" (63), "angrepp" (260), "försvar" (267). Romanens tre kontiguitetsblockerande strategier radikaliseras genom en konsekvent hyperbolisering. Diegesens sprickor kopplas till förstorande adjektiv som "hög" (7), "väldig" (74), "förfärlig" (260), "Oändlig" (200). De exponeras genom upprepning och kombinering: "väggar, väggar" (37), "Ett gap. En avgrund. En sådan avgrund" (224). De förstärks via

102 Jfr Dorothea Vorländer, Deus Incarnatus. Die Zweinaturenchristologie Luthers bis 1521, Witten 1974, s. 13f., 84f., 217f.; Ulrich Asendorf, Gegreuzigt und Auferstanden. Luthers Herausforderung an die moderne Christologie, Hamburg 1971, s. 258; Althaus, Die Theologie, s. 32.

${ }^{103}$ Flasch, "Logik", s. 48; jfr Rist, Augustine, s. 11; Geerlings, s. 216; Greshake, Geschenkte Freiheit, s. 44; Dinkler, Die Anthropologie, s. 127ff.; Ebeling, s. 194; Althaus, Die Theologie, s. 112f.

${ }^{104}$ Augustinus, De civitate Dei 15,4 (PL 41,440), 18,22 (PL 41,578); förf:s Confessiones 8,5,11 (PL 32,754), 8,10,24 (PL 32,760), 8,8,19 (PL 32,757); förf:s De peccatorum meritis 2,19,32 (PL 44,170); jfr Geerlings, s. 215ff.; Maier, s. 118ff., 128, 165; Flasch, "Streitfragen", s. 265; TeSelle, s. 286.

${ }^{105}$ Martin Luther, In epistolam ad Galatas commentarius 2,16 (WA 40,1,221); förf:s De servo arbitrio (WA 18,774); jfr Karin Bornkamm, Luthers Auslegung des Galaterbriefes 1519 und 1531. Ein Vergleich, Berlin 1963, s. 90; Max Josef Suda, Die Ethik Martin Luthers, Göttingen 2006, s. 112; Vorländer, s. 89; Althaus, Die Theologie, s. 32 .

${ }^{106}$ Jfr Augustinus, De civitate Dei 13,1ff., (PL 41,377ff.); Greshake, Geschenkte Freiheit, s. 41; Scheffczyk, s. 199ff., 209ff.; Dinkler, Die Anthropologie, s. 82ff.

${ }^{107}$ Augustinus, Ad Simplicianum 1,2,16 (PL 40,121); förf:s Confessiones 1,18,28 (PL 32,673), 2,3,8 69 (PL 32,678), 8,4,9 (PL 32,753), 8,8,19 (PL 32,757). 
totalitetsuttryck, ges universell status och omsätts i kosmiska visioner: romanens värld framställs som "den stora Världs-Klyftan" (277). Avgränsade från varandra får diegesens samtliga komponenter ett påfallande drag av oåtkomlighet. Gårdskarlen konstaterar gång på gång att "det var som om han inte kunde komma fram, där var något emellan" (139). De spatialt koncipierade gränslinjerna förstärks ytterligare genom att de förses med temporal permanens. De framställs som orubbliga (253), ointagliga (66), obotliga (57), varar "miljarder år" (164). Även då berättaren ibland ger ett intryck av att vilja relativisera sina diegetiska gränslinjer, låter de sig aldrig helt utplånas. De frekventa fraserna med det komparativa adverbet nästan - "nästan förvandling" (157), "nästan inne i himlen" (80), "nästan i paradisets ordning" (141) - påminner om den principiella inkommensurabiliteten mellan diegesens olika sfärer.

Berättaren projicerar sina diskontinuitetsalstrande strategier på tidsaxeln och konstruerar romanens händelseförlopp kring markanta brytpunkter. Tydlig i verket är benägenheten att dra ihop utdragna förlopp till momentana språng. Solens dagliga vandring på himlavalvet tar visserligen många timmar i anspråk, men för dykungens inspärrade blick kontraheras den till ett enda ögonblick:

Det var ögonblicket när allt kunde hända, han visste att det hände på ett ögonblick - just när ljuset passerade, just när cellen stod i brand. Ett ögonblick -. (37)

Gestalternas livsöden centreras kring dramatiska engångshändelser, som radikalt ändrar deras öden. Dykungens trygga existens hos fosterföräldrarna avbryts då han "förverkade allt och förvisades" (35). Berättaren låter en och samma gestalt uppleva många sådana episoder, även då det riskerar att upplösa intrigens koherens. Flickan lever ett lyckligt liv som i "paradiset" (57) ända tills "något betydelsefullt och obotligt" (57) händer med henne då hon "första gången" (57) binds fast. Men berättaren glömmer snart denna obotliga tilldragelse och återställer flickans paradisiska oskuld ("en fanns som ännu inte hade lärt sig gråta” (63)) bara för att möjliggöra nästa fall i hennes liv. Romanens språngartade intrigföring genererar ett helt komplex av diskontinuitetssignalerande grepp. Nya episoder introduceras ofta med en regiformel som antyder deras exceptionella status i historien: "Och det hände henne detta" (15). Narrationen övergår då vanligen från durativa till terminativa verb. Frekventa är adverbiala beteckningar för det momentana, överraskande, omotiverade: "med ens" (58), "oförmodat" (92), "oväntat" (93), "utan anledning" (64). En nyckelposition bland denna sorts uttryck intar ordet plötsligt, vars diskontinuitetsalstrande verkan potentieras genom utropstecken, polysyndeton, anafor, omtagning, upprepning: "Men då plötsligt! / Plötsligt!" (153).

Medan syntetiska tankeparadigm inom kristendomen ger företräde åt metonymiska grepp, privilegierar Augustinus och Luther metaforen. Den metaforkonstituerande ekvivalensprincipen som förenar "similarity and dissimilarity, synonymity and antonymity"108 dominerar de båda teologernas diskurs och metaforiserar deras argumentation och språk. I Augustinus nådelära tvingas de metonymiskt koncipierade termerna för mänskligt kollektiv (gemenskap, samhälle, släkte, massa) in i det kombinerade motsats- och

${ }^{108}$ Roman Jakobson, "Closing Statement: Linguistics and Poetics", i: Style in Language, red. Thomas A. Sebeok, New York-London 1960, s. 358. 
likhetsrastret skyldigt vs oskyldigt ("vel debita vel non debita"). ${ }^{109}$ Hos Luther beskrivs förhållandet mellan det andliga och det världsliga regementet som en samverkan mellan Guds högra och vänstra hand, men denna metonymiska bild underordnas genast den ekvivalensstyrda relationen mellan Guds och djävulens rike. ${ }^{110}$ I Dykungens dotter märks ekvivalensprincipens dominans inte minst på det verbalt-bildspråkliga planet. Berättaren sammanför ord med samma suffix och ändelser, använder assonanser och allitterationer, upprepar ord och fraser, radar upp syntaktiska parallellismer, genererar ständigt nya metaforiska uttryck: slakt för krig, padda för liv, snö för förtvivlan, labyrint för hus, minne för foster, foster för tanke, eld för sol, sol för barn, djur för maskin, maskin för människa etc. Alla dessa metaforrelaterade medel är verksamma även då texten fokuserar diegesens metonymiska relationer. Flickans upplevelse av naturens levande allförening (206) är visserligen metonymisk till sin ontologiskas struktur men återges i berättelsen via ett helt komplex av metaforiska bilder: naturen är "en väv av liv", tankarna bildar "en tom ond bur", dyskogen får "lungor och hjärta" (206), jorden upptar flickan i sin fuktiga "mage" (206). På ett motsvarande sätt arrangeras romanens övergripande betydelseproducerande mekanismer. I den mån berättaren speglar den svenska 1900-talsverkligheten dominerar metonymin som berättelsens organisationsprincip. Diegesens olika element placeras i ett geografiskt och historiskt sammanhang genom ett nät av kontiguitetsbaserade kopplingar. Men så fort berättaren underkastar detta empiriska material sin offensiva tolkning tar metaforen överhanden. Den konkreta urbana topografin visar sig dölja ett underliggande mönster av likhets- och motsatsrelationer, som på överfört vis aktualiserar väsentliga antropologiska sanningar.

\section{Slutsatser}

Eftersom denna artikel inledningsvis formulerat tre syften ska den också avslutas med tre sorters slutsatser. Analysen har demonstrerat att en icke-generisk arketext är fullt möjlig. Den augustinsk-lutherska diskurstyp som här rekonstruerats är på många sätt porös: den har ingen tydlig tillslutning utan kan fritt utvidgas och kompletteras. Den utmärker sig genom en låg grad av normativitet och beskriver snarare det vanligen förekommande än det undantagslösa. Den styrs inte syllogistiskt av någon överordnad princip utan bygger på olika typer av binariteter som står i opposition till diskurskoncept av varierande konfessionell och historisk proveniens. Den eftersträvar vidare inte någon fullkomlig balans mellan de båda teologerna utan kan på vissa punkter starkare hörsamma en av dem. Den bygger på komponenter som var för sig inte rymmer någon diskurstypisk kvalitet utan som blir paradigmatiska först i samspel med de övriga parametrarna. Den är slutligen inte självtillräcklig som formellt-logisk konstruktion utan hämtar ständigt stöd från tankeparadigmets idénivå. Kort sagt är den behäftad med alla de strukturella ofullkomligheter som är inskrivna i begreppen diskurs och diskurstyp. Men samtidigt kännetecknas denna öppna arketext av en påfallande hög applicerbarhet och låter sig lätt tillämpas i litteraturstudier. Inom svensk litteraturvetenskap skulle den exempelvis kun-

${ }^{109}$ Augustinus, Ad Simplicianum 1,2,16 (PL 40,120).

110 Jfr Adam, Lehrbuch, II, s. 161ff., 262; Paul Althaus, "Luthers Lehre von den beiden Reichen im Feuer der Kritik", Luther-Jahrbuch 24 (1957), s. 42. 
na tas i bruk för att undersöka världs- och människogestaltningen i andra konvertiters författarskap. Tillfrågad om sina teologiska inspiratörer hänvisar Torgny Lindgren gärna till nykatolska personalister. ${ }^{111}$ Men vilar inte hans framställningar av den laglösa nåden snarare just på den augustinsk-lutherska diskursorganisationen?

Denna artikel har satt den augustinsk-lutherska arketexten i arbete för att få svar på både en applikativ och en teoretisk fråga. På det applikativa planet har den arketextuella analysen visat att Dykungens dotter med slående tydlighet inkarnerar den augustinsk-lutherska diskurstypen och därmed inbjuder till tolkningar via augustinska intertexter, som Trotzig explicit tagit avstånd från. I en essä observerar hon att Vladimir Nabokov under hela sitt liv distanserat sig från Dostojevskij samtidigt som han på det inre, halvmedvetna planet influerats av dennes verk. I denna "skapande förträngning" vill Trotzig se en väsentlig källa till Nabokovs kreativitet. ${ }^{112}$ Artikelns applikativa resultat kan uppfattas som ett indicium på att hon själv på ett analogt sätt tränger bort Augustinus och Luther.

Det teoretiska svaret är svårare att tolka. I Introduction à l'architexte visar Genette en påtaglig osäkerhet inför arketextbegreppets bestämningar. I större delen av sitt resonemang företräder han uppfattningen att arketexten konstitueras av två sorters parametrar: dels tematiska, objektbundna, dels baserade på utsägelsemodus. ${ }^{113}$ Som typisk strukturalist koncipierar han utsägelsemodus som ett kvasilingvistiskt, ahistoriskt fenomen med en hög grad av determinering och i analogi till sina narratologiska verktyg. På samma sätt som varje språkbrukare måste välja mellan bestämda böjningskategorier och på samma sätt som varje berättare med samma nödvändighet väljer mellan ett bestämt antal alternativa narrativa figurer ställs, menar Genette, varje litterär text ofrånkomligen inför ett val mellan vissa binärt reglerade modustyper. ${ }^{114}$ Men i studiens näst sista sektion gör Genette en teoretisk volt och introducerar en tredje arketextuell parametertyp: den formella. Även den koncipieras efter ett kvasilingvistiskt mönster och kopplas till binariteten poesi vs prosa. De arketextuella "déterminations" blir nu alltså tre - "thématiques, modales et formelles" - alla tre betraktade som "relativement constantes et transhistoriques". ${ }^{115}$ I den fingerade, lekfullt-självironiska dialog som fyller studiens sista sektion lägger Genette fram ytterligare en taxonomi över arketextens bestämningar/domäner. Denna sista systematik är den bredaste och omfattar genologi (genrer), modistik (utsägelsemodus), figurologi (stil), morfologi (prosa/poesi) och tematik - med förbehåll att ytterligare arketextuella bestämningar eventuellt fortfarande väntar på sin upptäckare. ${ }^{116}$ Den inlagda polemiken mot den hermeneutiskt orienterade stilforskaren Leo Spitzer indikerar att de uppräknade determinanttyperna/domänerna är konstruerade på Genettes vanliga strukturalistiskt-transhistoriska vis. Hur förhåller sig den augustinsk-lutherska arketexten till detta generellt anlagda tankebygge? Av den genomförda tillämpningen kan man dra tre teoretiska slutsatser. Medan den första ger ett bekräftande stöd åt Genettes typologi, ställer de övriga två hans resonemang i ett mer problematiskt ljus. För det första är Genettes

\footnotetext{
111 Jfr Kaj Schueler, Torgny om Lindgren, Stockholm 2013, s. 176.

112 Birgitta Trotzig, "Det otillgängliga barnet", Artes 26/1 (2000), s. $41 \mathrm{f}$.

113 Jfr Genette, Introduction, s. 66, 75ff.

114 Jfr ibid., s. 68ff., 74ff., 80ff.

115 Ibid., s. 83 .

116 Ibid., s. $89 f$.
} 
modell så vitt koncipierad att den täcker alla de arketextuella determinanter som applikationen satt i spel. Den augustinsk-lutherska arketexten omfattar bland annat grammatiska kategorier (numerus, person, tempus), narrativa figurer (perspektiv, distans), logiska operationer (analys), troper (metafor) och ordklasser (disjunktiva och adversativa konjunktioner). Alla dessa parametrar beaktas på ett eller annat sätt av Genettes sista taxonomi. Att de inom den augustinsk-lutherska diskurstypen inte är självtillräckliga som arketextuella bestämningar utan överdetermineras av avancerade idékomplex står inte heller i strid med Genettes teori. Hans kategorier tematik och tematisk konstans är så allmänt tänkta att de rymmer alla typer av semantiska sammanhang oberoende av deras kognitiva komplikationsgrad. ${ }^{117}$ Den andra teoretiska slutsatsen är att bara några få av den augustinsk-lutherska diskurstypens bestämningar lever upp till Genettes föreställning om arketextuell konstans. Till dem hör exempelvis oppositionerna singulär/ plural och fokaliserad/icke-fokaliserad, som båda visar en lingvistisk eller kvasilingvistisk karaktär. Men andra parametrar följer inte den sortens binära logik. Värdeabsolutismen är ingen nödvändig följd av det analytiska argumentationssättet. De flesta av arketextens språkmarkörer används på ett hermeneutiskt sätt som snarare leder tanken till ett traditionellt, spitzerskt stilbegrepp än till Genettes "stilistique transcendante"118 på samma sätt som många av modellens determinanter snarare förankras i kvantitet och gradering än i uteslutande kvalitativa motsatser. Några av arketextens bestämningar ifrågasätter explicit det strukturalistiska synsättet. Medan Jakobson, inspirerad av de Saussure, koncipierar selektionsaxelns styrande princip, ekvivalensprincipen, bipolärt som en kombination av likhet och motsats, definierar han kombinationsaxelns huvudprincip, kontiguitetsprincipen, monopolärt som närhet/beröring/kongruens. ${ }^{119}$ En av den augustinsk-lutherska arketextens viktigare bestämningar, diskontinuitet (förnekad närhet), betraktar Jakobson som en patologisk "contiguity disorder" utan täckning i de normala språkaktiviteterna. ${ }^{120}$ För det tredje slutligen relativiserar den augustinsk-lutherska diskurstypen gränserna mellan Genettes arketextuella parametrar/domäner. I Introduction à l'architexte gör han ett stort nummer av att demonstrera en principiell skillnad mellan modussystem och genresystem, mellan arketext och arkegenre. ${ }^{121}$ Både den augustinisk-lutherska diskurstypen och dess applikation på Dykungens dotter visar att den distinktionen är mycket relativ. Metaforisering och metonymisering är tropbaserade praktiker med bas i språkets selektions- och kombinationsaxel, men i Trotzigs roman får de närmast automatiskt generiska konsekvenser genom att främja samhällsromanens resp. parabelns genredrag. Att metonymiseringen ligger till grund för den realistiska prosan visar inte minst Jakobson. ${ }^{122}$

Det vore förmätet att utifrån dessa tre teoretiska slutsatser försöka fälla någon bindande dom över Genettes arketextualitetsbegrepp, eftersom de bygger på en enda skissartat konstruerad arketext och en enda applikation. Men åtminstone en övergripande reflektion låter sig formuleras: $\mathrm{i}$ sin konstruktion av arketextualitetsbegreppet arbetar struk-

\footnotetext{
117 Jfr ibid., s. 25f., 40, 57, 66 och passim.

118 Ibid., s. 89.

${ }^{119}$ Jfr Roman Jakobson, "Two Aspects of Language and Two Types of Aphatic Disturbances", i: förf:s Selected Writings. II. Word and Language, The Hague-Paris 1971, s. 244, 259; förf:s "Closing Statement", s. 358.

120 Jakobson, "Two Aspects", s. 250ff.

121 Genette, Introduction, s. 63, 69.

122 Jfr Jakobson, "Closing Statement", s. 375; förf:s ”Two Aspects", s. 255ff.
} 
turalisten Genette med språket som en sorts kognitiv modell. Detta lingvistiska tänkesätt är möjligen motiverat då arketexten identifieras med en litterär genre. Men då det arketextuella perspektivet öppnas mot mer komplexa diskurstyper blir språktänkandet en uppenbar begränsning. Fallet diskontinuitet är signifikativt. Så länge det handlar om att foga samman rena språkkomponenter - fonem, morfem, ord, satser - fungerar kontiguitetsprincipen monopolärt som en närhetsrelation och diskontinuiteteten kan avskrivas som språklig störning. Men på det tankeparadigmatiska planet behöver inte separationen vittna om någon diskursiv afasi. Den kristna teologin har upprepade gånger visat att den förnekade beröringen fungerar som ett lika effektivt diskursgenererande verktyg som den av strukturalisterna godkända, språkligt motiverade förnekade likheten. Om arketextteorin ska kunna omfatta mer avancerade kognitiva sammanhang borde den alltså mer konsekvent grundas på diskursanalytiska och hermeneutiska premisser. Som denna artikel haft ambitionen att visa behöver denna teoretiska förskjutning - och strukturella uppluckring - inte minska arketexternas heuristiska värde.

\section{LITTERATURFÖRTECKNING}

Adam, Alfred, "Das Fortwirken des Manichäismus bei Augustin", Zeitschrift für Kirchengeschichte 66 (1958), s. 1-15.

-, Lehrbuch der Dogmengeschichte, Gütersloh $1965 \mathrm{ff}$.

Allen, Graham, Intertextuality, Abingdon 2011.

Althaus, Paul, "Luthers Lehre von den beiden Reichen im Feuer der Kritik", Luther-Jahrbuch 24 (1957), s. $40-68$.

-, Die Theologie Martin Luthers, Gütersloh 1962.

Andersson, Helen, "Litteratur som virtuell verklighet och drömvision - exemplet Dykungens dotter", i: Mediekulturer. Hybrider och förvandlingar, red. Claes-Göran Holmberg \& Jan Svensson, Stockholm 2004, s. 18-52.

Andersson, Pär-Yngve, Överskridandets strategier. Lyrisk romankonst och dess uttryck hos Rosendahl, Trotzig och Lillpers, Örebro 2004.

Anton, John Peter, Aristotle's Theory of Contrariety, London 1957.

Arseniew, Nicolas von, Ostkirche und Mystik, München 1925.

Asendorf, Ulrich, Eschatologie bei Luther, Göttingen 1967.

-, Gekreuzigt und Auferstanden. Luthers Herausforderung an die moderne Christologie, Hamburg 1971.

Augustinus, Opera omnia, i: Patrologiae cursus completus. Series Latina, red. Jacques-Paul Migne, Paris 1841ff., XXXII-XLVII (= PL).

-, Les Confessions. Livres I-VII, red. Martin Skutella, Paris 1962.

Augustinus. De civitate Dei, red. Christoph Horn, Berlin 1997.

Augustinus-Lexikon, red. Cornelius Mayer, Basel 1986ff.

Bak, Krzysztof, Den intersubjektiva synden i Birgitta Trotzigs Dykungens dotter, Kraków 2005.

-, "Subjektivitetens tätaste mörker. Om tolkning av bildkonst hos Birgitta Trotzig", i: Det åskådliga och det bottenlösa. Tankar om konst och humaniora tillägnade Margaretha Rossholm Lagerlöf, red. Tomas Björk, Peter Gillgren m.fl., Stockholm 2010, s. 13-19.

-, "Varats avigsida. Om en ontisk tolkning av Birgitta Trotzigs Dykungens dotter", Kritiker 93/17-18 (2010), s. 112-122.

-, "Den kluvna kärnan. Läsningar av Birgitta Trotzigs 'Ormflickan'”, Acta Universitatis Carolinae. Philologica. Germanistica Pragensia 21 (2012), s. 87-118.

Barth, Karl, Hiob, red. Helmut Gollwitzer, Neukirchen-Vluyn 1966.

Bilanz der Theologie im 20. Jahrhundert. Perspektiven, Strömungen, Motive in der christlichen und nichtchristlichen Welt, red. Herbert Vorglimler \& Robert vander Gucht, Freiburg/B $1969 f$. 
Billicsich, Franz, Das Problem des Übels in der Philosophie des Abendlandes, Wien-Köln 1952ff.

Blom, K. Arne, '”Jag tyckte Martin Luther hade fel!'”, Tidningen Boken 12/5 (1998), s. 14-18.

Bornkamm, Karin, Luthers Auslegung des Galaterbriefes 1519 und 1531. Ein Vergleich, Berlin 1963.

Burke, Kenneth, The Rhetoric of Religion. Studies on Logology, Berkeley 1970.

Campenhausen, Hans von, "Die Bilderfrage als theologisches Problem der alten Kirche", Zeitschrift für Theologie und Kirche 49 (1952), s. 33-60.

Collmar, Lars, "Varför kallas mina böcker svarta? Verkligheten är ju mycket värre", Vår Kyrka 112/47 (1973), s. 5-7.

-, "Själv håller jag mig till den negativa teologin", Vår Kyrka 116/27-28 (1977), s. 2-3.

Congar, Yves M.-J., "Neuf Cents ans après. Notes sur le 'Schisme oriental'", i: 1054-1954. L'Église et les Églises. Neuf siècles de douloureuse séparation entre l'Orient et l'Occident. Études et travaux sur l'unité chrétienne offers à Dom Lambert Beauduin, Chevetogne 1954, I, s. 3-95.

-, La Foi et la Théologie, Tournai 1962.

Dictionnaire d'analyse du discours, red. Patrick Charaudeau \& Dominique Maingueneau, Paris 2002.

Dihle, Albrecht, The Theory of Will in Classical Antiquity, Berkeley 1982.

Dinkler, Erich, Die Anthropologie Augustins, Stuttgart 1934.

-, "Augustins Geschichtsauffassung", Schweizer Monatshefte 34 (1954), s. 514-526.

Duchrow, Ulrich, Christenheit und Verantwortung. Traditionsgeschichte und systematische Struktur der Zweireichenlehre, Stuttgart 1970.

Ebeling, Gerhard, Luther. Einführung in sein Denken, Tübingen 1965.

Escribano-Alberca, Ignacio, Glaube und Gotteserkenntnis in der Schrift und Patristik, Freiburg/B 1974.

Evans, Gillian R., Augustine on Evil, Cambridge 1982.

Evdokimov, Paul, Die Frau und das Heil der Welt, München 1960.

Flasch, Kurt, Augustin. Einführung in sein Denken, Stuttgart 1980.

Friis, Elisabeth, "Intertextualitet", i: Litteratur. Introduktion till teori och analys, red. Lasse Horne Kjældgaard m.fl., Lund 2015, s. 147-159.

Genette, Gérard, Introduction à l'architexte, Paris 1979.

-, Palimpsestes. La littérature au second degré, Paris 1982.

Gilson, Étienne, Introduction a l'étude de Saint Augustin, Paris 2003.

Godard, Barbara, "Intertextuality", i: Encyclopedia of Contemporary Literary Theory. Approaches, Scholars, Terms, red. Irena M. Makaryk, Toronto 1993, s. 568-571.

Greshake, Gisbert, Gnade als konkrete Freiheit. Eine Untersuchung zur Gnadenlehre des Pelagius, Mainz 1972.

-, Geschenkte Freiheit. Einführung in die Gnadenlehre, Freiburg 1977.

Gross, Julius, Geschichte des Erbsündendogmas. Ein Beitrag zur Geschichte des Problems vom Ursprung des Übels, München-Basel 1960ff.

Hacker, Paul, Das Ich im Glauben bei Martin Luther, Graz 1966.

Harnack, Adolf von, Lehrbuch der Dogmengeschichte, Tübingen 1990.

-, Dogmengeschichte, Tübingen 1991.

Heiler, Friedrich, Die Ostkirchen, München-Basel 1971.

Holte, Ragnar, Beatitudo och sapientia. Augustinus och de antika filosofiskolornas diskussion om människans livsmål, Stockholm 1958.

Häring, Hermann, Die Macht des Bösen. Das Erbe Augustins, Zürich 1979.

Jakobson, Roman, "Closing Statement: Linguistics and Poetics", i: Style in Language, red. Thomas A. Sebeok, New York-London 1960, s. 350-377.

-, Selected Writings. II. Word and Language, The Hague-Paris 1971.

Jay, Martin, Downcast Eyes. The Denigration of Vision in Twentieth-Century French Thought, Berkeley 1993.

Jefferson, Ann, "Autobiography as Intertext. Barthes, Sarraute, Robbe-Grillet", i: Intertextuality. Theories and Practices, red. Michael Worton \& Judith Still, Manchester-New York 1990, s. 108-129.

Joest, Wilfried, Gesetz und Freiheit. Das Problem des Tertius usus legis bei Luther und die neutestamentliche Parainese, Göttingen 1956.

Jüngel, Eberhard, Zum Wesen des Friedens. Frieden als Kategorie theologischer Anthropologie, München 1983. 
Kraus, Hans-Joachim, Psalmen, Neukirchen 1960.

Kullbom, Pierre, "Religion, litteratur och nutid - ett samtal med Birgitta Trotzig", Signum 12/3 (1986), s. 69-73.

Lampey, Erich, Das Zeitproblem nach den Bekenntnissen Augustins, Regensburg 1960

Logik des Schreckens. Augustinus von Hippo. De diversis quaestionibus ad Simplicianum I 2, red. Kurt Flasch, Mainz 1995.

Lohse, Bernhard, Martin Luther. Eine Einführung in sein Leben und sein Werk, München 1981.

Lossky, Vladimir, Die mystische Theologie der morgenländischen Kirche, Graz 1961.

Lubac, Henri de, Catholicisme. Les aspects sociaux du dogme, Paris 1983.

Luther, Martin, Werke. Kritische Gesamtausgabe, Weimar 1883ff. (= WA)

Maier, Franz Georg, Augustin und das antike Rom, Stuttgart-Köln 1955.

Markus, Robert A., Saeculum. History and Society in the Theology of St Augustine, Cambridge 1970.

Marrou, Henri-Irénée, Saint Augustin et la fin de la culture antique, Paris 1938.

Martinez, Matias, "Intertextualität", i: Metzler Lexikon Literatur. Begriffe und Definitionen, red. Dieter Burdof m.fl., Stuttgart-Weimar 2007, s. 357-358.

Matthews, Gareth B., "Augustine's First-Person Perspective", i: Augustine and Philosophy, red. Phillip Cary m.fl., Lanham 2010, s. 41-60.

McHale, Brian, "Free Indirect Discourse. A Survey of Recent Accounts", PTL. A Journal for Descriptive Poetics and Theory of Literature 3 (1978), s. 249-287.

Miočević, Ljubica, "Intertextualitet", i: Litteraturvetenskap I, red. Sigrid Schottenius Cullhed m.fl., Lund 2020, s. 194-196.

Moraru, Christian, "Intertextuality", i: Routledge Encyclopedia of Narrative Theory, red. David Herman m.fl., London-New York 2008, s. 256-261.

Morgan, Thaïs, "The Space of Intertextuality", i: Intertextuality and Contemporary American Fiction, red. Patrick O’Donnell \& Robert Con Davis, Baltimore-London 1989, s. 239-279.

Nagel, Peter, Die Motivierung der Askese in der alten Kirche und der Ursprung des Mönchtums, Berlin 1966.

Nilsson, Nils Gunnar, "'Den årstid där evigheten börjar'”, Sydsvenska Dagbladet 7.4.1985.

O'Daly, Gerard, Augustine's Philosophy of Mind, London 1987.

Olsson, Ulf, I det lysande mörkret. En läsning av Birgitta Trotzigs De utsatta, Stockholm 1988.

Oort, Johannes van, Jerusalem and Babylon. A Study into Augustine's City of God and the Sources of His Doctrine of the Two Cities, Leiden 1991.

Pesch, Otto Hermann, Theologie der Rechtfertigung bei Martin Luther und Thomas von Aquin. Versuch eines systematisch-theologischen Dialogs, Mainz 1967.

Pesch, Otto Hermann \& Albrecht Peters, Einführung in die Lehre von Gnade und Rechtfertigung, Darmstadt 1981.

Peters, Albrecht, Glaube und Werk. Luthers Rechtfertigungslehre im Lichte der Heiligen Schrift, Berlin-Hamburg 1962.

Pirholt, Mattias, Ett språk, ett spår. En studie i Birgitta Trotzigs författarskap, Stockholm-Stehag 2005.

Pfister, Manfred, "Konzepte der Intertextualität", i: Intertextualität. Formen, Funktionen, anglistische Fallstudien, red. Ulrich Broich \& Manfred Pfister, Tübingen 1985, s. 1-30.

Pieper, Franz \& J.T. Mueller, Kristen dogmatik, Uppsala 1985.

Pleijel, Agneta, "Människan, skapelsen, skapandet. Ett samtal med Birgitta Trotzig", Ord och Bild 91/1 (1982), s. 3-18.

Quinones, Ricardo J., Dualisms. Agons of the Modern World, Toronto 2007.

Ricœur, Paul, Le conflit des interprétations. Essais d'herméneutique, Paris 1969

-, "Qu'est-ce qu'un texte? Expliquer et comprendre", i: Hermeneutik und Dialektik. Aufsätze II, red. Rüdiger Bubner m.fl., Tübingen 1970, s. 181-200.

-, Le Mal. Un défi à la philosphie et à la théologie, Genève 2004.

Rist, John M., "Augustine on Free Will and Predestination", The Journal of Theological Studies 20 (1969), s. $420-447$.

-, Augustine. Ancient thought baptized, Cambridge 1994.

Rottmanner, Odilo, Geistesfrüchte aus der Klosterzelle. Gesammelte Aufsätze, red. Rupert Jud, München 1908. 
Ruge-Jones, Philip, Cross in Tentions. Luther's Theology of the Cross as Theologico-social Critique, Eugene 2008

Scheffczyk, Leo, Urstand, Fall und Erbsünde. Von der Schrift bis Augustinus, Freiburg/B 1981.

Schlink, Edmund, "Gesetz und Evangelium als kontroverstheologisches Problem", Kerygma und Dogma 3 (1961), s. 1-35.

Schueler, Kaj, Torgny om Lindgren, Stockholm 2013.

Schulz, Hans-Joachim, "Die 'Höllenfahrt' als 'Anastasis'. Eine Untersuchung über Eigenart und dogmengeschichtliche Voraussetzungen byzantinischer Osterfrömmigkeit", Zeitschrift für katholische Theologie 81 (1959), s. 1-66.

Schwanz, Peter, Imago Dei als christologisches Problem in der Geschichte der Alten Kirche von Paulus bis Clemens von Alexandrien, Halle 1970.

Schäfer, Peter, Das Schuldbewusstsein in den Confessiones des heiligen Augustinus. Eine religionspsychologische Studie, Würzburg 1930.

Seeberg, Reinhold, Lehrbuch der Dogmengeschichte, Basel-Stuttgart 1960.

Slenczka, Notger, "Luther's Anthropology", i: The Oxford Handbook of Martin Luther Theology, red. Robert Kolb m.fl., Oxford 2014, s. 212-232.

Solignac, Aimé, "Les excès de l"intellecus fidei' dans la doctrine d'Augustin sur la grâce", Nouvelle Revue Théologique 110/6 (1988), s. 825-849.

Stierle, Karlheinz, "Werk und Intertextualität", i: Dialog der Texte. Hamburger Kolloquium zur Intertextualität, red. Wolf Schmid \& Wolf-Dieter Stempel, Wien 1983, s. 7-26.

Ström, Eva, "Den inre orten", Sydsvenska Dagbladet 28.8.1988.

Suda, Max Josef, Die Ethik Martin Luthers, Göttingen 2006.

Svenska kyrkans bekännelseskrifter, Stockholm 1979.

Teilhard de Chardin, Pierre, L’avenir de l'homme, Paris 1959.

-, Comment je crois, Paris 1969.

-, Le cour de la matière, Paris 1976.

TeSelle, Eugene, Augustine the Theologian, London 1970.

Thümmel, Hans Georg, Bilderlehre und Bilderstreit. Arbeiten zur Auseinandersetzung über die Ikone und ihre Begründung vornehmlich im 8. und 9. Jahrhundert, Würzburg 1991.

Trotzig, Birgitta, "Efterskrift 1974", i: Teilhard de Chardin, red. Jarl Hemberg, Stockholm 1975, s. 64-67.

-, "Tankens arbetare har i vårt århundrades mörker en uppgift - att skilja dödsprincip från livsprincip", Expressen 9.3.1981.

-, "Det outhärdliga får inte glömmas", Dagens Nyheter 17.4.1983.

-, [svar på] "Enkät om Ekelöf: vad han betytt för lyriker och andra", Allt om Böcker 1984/2, s. 12.

-, Dykungens dotter. En barnhistoria, Stockholm 1985.

-, "Vi håller på att vakna", Aftonbladet 27.9.1987.

-, "Det otillgängliga barnet", Artes 26/1 (2000), s. 41-45.

[Trotzig, Birgitta \& Martin Lönnebo], "Mystikens språk och erfarenhet. Ett samtal mellan Birgitta Trotzig och Martin Lönnebo", i: Mystik. Samtal och föredrag, Linköping 1993, s. 1-18.

Tyrberg, Anders, Anrop och ansvar. Berättarkonst och etik hos Lars Ahlin, Göran Tunström, Birgitta Trotzig, Torgny Lindgren, Stockholm 2002.

Uspenskij, Boris, A Poetics of Composition. The Structure of the Artistic Text and Typology of a Compositional Form, Berkeley 1973.

Vorländer, Dorothea, Deus Incarnatus. Die Zweinaturenchristologie Luthers bis 1521, Witten 1974.

Yannaras, Christos, Person und Eros. Eine Gegenüberstellung der Ontologie der griechischen Kirchenväter und der Existenzphilosophie des Westens, Göttingen 1982.

Zaremba, Maciej, "'Jag går i vilka kyrkor jag vill'”, Dagens Nyheter 20.12.1998.

Zernov, Nicolas, "Rome and Orthodoxy. Is Reunion Possible?", i: Pluralisme et Ecuménisme en Recherches Théologiques. Mélanges offerts au R.P. Dockx, O.P., Paris 1976, s. 237-244.

Krzysztof Bak

Stockholm University and Jagiellonian University, Cracow

krzysztof.bak@uj.edu.pl 